\title{
Secondary Science and Mathematics Teachers' Environmental Issues Engagement through Socioscientific Reasoning
}

\author{
David C. Owens ${ }^{1 *}$, Benjamin C. Herman ${ }^{2}$, Robert T. Oertli ${ }^{2}$, Amy A. Lannin ${ }^{2}$, Troy D. Sadler ${ }^{3}$ \\ ${ }^{1}$ Georgia Southern University, Department of Middle Grades and Secondary Education, 11935 Abercorn St., Savannah, GA, USA \\ 2 University of Missouri, Department of Learning, Teaching, \& Curriculum, 303 Townsend Hall, Columbia, MO, USA \\ ${ }^{3}$ University of North Carolina at Greensboro, School of Education, 1300 Spring Garden St., Greensboro, NC, USA
}

Received 14 May $2018 \cdot$ Revised 16 October 2018 • Accepted 13 December 2018

\begin{abstract}
Among the many responsibilities of $\mathrm{K}-12$ educators is to promote the development of environmental literacy among their students. Contentious environmental issues are often considered socioscientific issues (SSl; e.g., climate change) in that they are rooted in science, but a myriad of non-scientific (e.g., cultural, political, economic, etc.) factors must be addressed if those issues are to be successfully resolved. Teachers often report being ill-equipped to address these non-scientific factors, which may be due to struggles with employing socioscientific reasoning (SSR). SSR includes understanding the complexity of SSI, engaging in perspective-taking and ongoing inquiry about SSI, employing skepticism when dealing with potentially biased information concerning SSI, and recognizing the affordances of science and non-science considerations in resolving those issues. In this study, mathematics and science teachers who engaged in an SSIoriented professional development demonstrated a range of sophistication across the dimensions of SSR, with science teachers tending to exhibit more sophistication in their SSR than mathematics teachers. Herein, we share and discuss the results of the study, including the prompts and scoring rubrics with exemplars, which can be used to prepare teachers to teach about contentious SSI and enable them to more effectively instruct and evaluate their students when doing so.
\end{abstract}

Keywords: environmental literacy, socioscientific issues, socioscientific reasoning, STEM education, teaching

\section{INTRODUCTION}

The severity and magnitude of environmental issues such as unsustainable agricultural practices and climate change have grown over time despite long-standing efforts to promote environmental awareness through various educational initiatives (e.g., UNESCO, 1976), including those that promote science, technology, engineering and mathematics (STEM) literacy (Yager, 1987). Part of this problem derives from the way in which definitions of STEM literacy aim to primarily leverage STEM content understanding as a means for solving complex issues. For instance, Balka (2011, p. 7) states STEM literacy is "the ability to identify, apply, and integrate concepts from science, technology, engineering, and mathematics to understand complex problems [personal, societal, economic] and to innovate to solve them". Framing STEM literacy in this manner is precisely what Zeidler (2016) and others have admonished, where the STEM disciplines are elevated above other ways of knowing when framing how to think about contentious scientific issues.

Promoting a deep understanding of the STEM concepts underpinning environmental issues has shown to be a necessary but insufficient part of mitigating and resolving these issues (Wals, Brody, Dillon, \& Stevenson, 2014). In this way, many environmental issues are considered socioscientific issues (SSI) in that the STEM disciplines alone cannot resolve them. The complexities, contentiousness, and multi-faceted social, political, economic, and often moral considerations associated with these issues makes their resolution challenging at best (Colucci-Gray, Camino,

(C) 2019 by the authors; licensee Modestum Ltd., UK. This article is an open access article distributed under the terms and conditions of the Creative Commons Attribution License (http://creativecommons.org/licenses/by/4.0/). \dcowens@georgiasouthern.edu (*Correspondence) $\square$ hermanb@missouri.edu $\square$ rto4gg@missouri.edu 


\section{Contribution of this paper to the literature}

- Environmental literacy is an unrealistic goal if teachers are ill-equipped to integrate the scientific and nonscientific aspects of environmental socioscientific issues (SSI).

- Teachers' responses to the SSI demonstrated a range of sophistication for each dimension of socioscientific reasoning (SSR), and science teachers appeared to exhibit more sophisticated reasoning than mathematics teachers.

- The SSR construct could be useful in designing learning experiences and assessments that contribute to environmental literacy in K-12 spaces using SSI and provide support for teachers who find engaging in SSI to be challenging.

Barbiero, \& Gray, 2006). Moreover, though several possible courses of action exist in response to these issues, each of those courses impose unique and unequal negative and positive impacts upon people and the environment. For this reason, a cross-disciplinary approach should be utilized where K-12 science, technology, engineering and mathematics (STEM) educators aid their students' engagement with SSI through sophisticated forms of perspective taking and reasoning beyond understanding STEM content and practices (Herman, 2015; Hodson, 2009; Lee et al., 2013). Such efforts are needed in the interest of helping students develop abilities that enable them to make responsible environmental decisions with the goal of improving the wellbeing of individuals, societies, and the environment (North American Association for Environmental Education [NAAEE], 2011).

However, if teachers are to help students in this manner, they must also possess sophisticated forms of perspective taking (Kahn \& Zeidler, 2016) and reasoning (Sakschewski, Eggert, Schneider, \& Bögeholz, 2014) as part of a suite of abilities requisite for implementing SSI instruction (Herman, Sadler, Zeidler, \& Newton, 2017). Our purpose here is to delineate the sophisticated forms of perspective taking and reasoning that STEM teachers should exhibit during SSI instruction as synonymous with socioscientific reasoning. We then draw from empirical data collected from secondary math and science teachers during an SSI instructional professional development to provide a profile of how they use SSR to engage SSI. These SSR profiles may inform future SSI professional development for STEM teachers.

\section{Socioscientific Reasoning for Engaging SSI}

Sadler, Barab and Scott (2007) present socioscientific reasoning (SSR) as a suite of practices that should be promoted in science classrooms with the goal of enhancing citizenship education. When defining this construct, Sadler et al. (2007) drew from earlier work (e.g., Kuhn, 1993) that claims both formal and informal reasoning play a role in the ways in which scientists and others conceptualize and develop scientific accounts. Formal reasoning conforms to the rules of logic and mathematics, while informal reasoning is typically more appropriate for considering ill-structured scientific topics that lack clear solutions based on the available data (Sadler, 2004; Zohar \& Nemet; 2002). It is contemplation of these types of reasoning that prompted Sadler et al. (2007) to put forth four dimensions of SSR (complexity, perspective-taking, inquiry, and skepticism) which were empirically situated through analyzing interview data collected from 24 middle school students as they engaged with a fictitious SSI focused on water quality issues and energy production and pollution. The result was an operational construct that could be employed to assess practices associated with the negotiation of SSI.

Since the introduction of the SSR construct by Sadler and colleagues (2007), lines of research have emerged providing insights as to the means by which individuals are employing SSR concerning complex societal issues. Thus, as SSR has become better understood, additional dimensions of SSR have been considered, and existing dimensions fleshed out (e.g., Kinslow, unpublished doctoral dissertation). For example, skepticism was included as a dimension when SSR was introduced (Sadler et al., 2007) as a means for generally considering the trustworthiness of claims made by individuals involved in the issue (Kolstø, 2001), but more recently, that dimension has been expanded to consider trustworthiness across SSI information sources, (e.g., interviews with stakeholders, social media, scientists' reports), as well as within the discipline of science itself, such as variation in reports from scientists employed by different stakeholders with vested interests (Osborne, 2007). Additional constructs have also been considered, such as recognizing that science affords an understanding of issues that informs their resolution but is limited in its ability to address all facets of an issue, such as non-science considerations (e.g., cultural, political, moral, etc.). (See Table 1 for operational definitions for each of the SSR dimensions addressed in this study). Presented below are several examples of research that demonstrates SSR is a crucial component of engaging SSI. However, due to the paucity of extant literature regarding teachers' SSR, the focus of the literature is on students' SSR. 
Table 1. Operational definitions of each dimension of SSR

\begin{tabular}{ll}
\hline SSR Dimension & Operational Definition \\
Complexity & $\begin{array}{l}\text { The recognition that SSI are open-ended problems that lack simple solutions; that SSI possess an } \\
\text { emergent systemic quality that makes them inherently complex; and that resolution cannot be achieved } \\
\text { by addressing isolated factors. }\end{array}$ \\
\hline Inquiry & $\begin{array}{l}\text { The appreciation that SSI are ill-structured and indeterminate because they entail complex social } \\
\text { considerations and are undergirded by frontier science, and therefore, SSI should be subject of ongoing } \\
\text { inquiry and investigations as a way of disentangling and mitigating these sources of uncertainty. }\end{array}$ \\
\hline Perspective-taking & $\begin{array}{l}\text { The acknowledgement that complex, multi-faceted SSI may be perceived differently by interested } \\
\text { parties, and that successful resolution requires the consideration of diverse and often opposing } \\
\text { scientific and non-scientific view-points. }\end{array}$ \\
\hline Skepticism & $\begin{array}{l}\text { The scrutinization of information sources as to their trustworthiness, including the identification of } \\
\text { potential biases, weighing of the robustness of evidence, and the integration of scientific and social } \\
\text { factors influencing SSI information sources, including scientists' reporting. }\end{array}$ \\
\hline $\begin{array}{l}\text { Affordances of science } \\
\text { and non-science } \\
\text { considerations }\end{array}$ & $\begin{array}{l}\text { The awareness of ways that science can and cannot account for natural phenomena associated with SSI, } \\
\text { and the extent that science, as compared with other considerations such as sociocultural factors and } \\
\text { ethical commitments, can appropriately provide avenues for SSI resolution. }\end{array}$ \\
\hline
\end{tabular}

Using a 3D multi-user virtual learning tool called Quest Atlantis, the Barab and colleagues (2007) engaged students in SSR through an SSI involving declining fish populations at a park that entailed economic and ecological ramifications as well as diverse stakeholder perspectives. Through a variety of data (e.g., video and direct observations of student discourse, interviews, and artifacts), Barab et al. (2007) demonstrated that the students successfully recognized the complexity of the SSI by acknowledging multiple perspectives as they attempted to balance economic and ecological concerns, consider multiple lines of evidence, and identify the strengths and weaknesses of their proposed solutions. However, while the students' adequately drew upon evidence through their solutions, inconsistent and flawed reasoning (e.g., resting on inaccurate scientific assumptions) was present among those solutions. Simonneaux and Simonneaux (2009) engaged students through SSI with a focus on diverse local and global issues including species reintroduction, global warming, and sustainable development. Through these experiences, the students' SSR varied by the contextual features of the SSI (e.g., emotional and cultural proximities) and was strongly influenced by their interactions and identification with stakeholders, and perceptions about those stakeholders' expertise. The students' SSR also demonstrated consideration of political views and skepticism concerning available information. However, they did not recognize the need for ongoing inquiry regarding the issues or the inherent uncertainty in understanding them.

In an attempt to assess SSR through more practical contexts than the Quest Atlantis virtual learning space, Sadler, Klosterman, and Topcu (2011) used student responses from a previous study (Sadler et al., 2007) to develop an open-ended, internet-based Socioscientific Issues Questionnaire with open-ended responses that focused on the three SSR constructs of complexity, ongoing inquiry, and multiple perspectives. Using modified codes from their previous work they demonstrated that while the students' content understanding changed over a three-week intervention, shifts in the students' SSR were unrealized. Despite the neutral findings, the study represented a significant advancement in terms of assessing SSR, which has shown to be important for more recent investigations that seek to determine the nuanced ways that students express SSR.

Morin and colleagues (2013) were interested in how digital technology could be used to support students' SSR. By way of a digital platform, students from different disciplines and continents were brought together to explore three SSI, including algal outbreaks resulting from fertilizer use in Brittany, the construction of a desalination plant in Melbourne, and global meat production. These authors found that structuring SSI instruction to include interdisciplinary within- and across-group collaboration and confrontation among individuals promoted an increase in the variety of perspectives shared and in the diversity of approaches to resolving the SSI, and resulted in higher levels of reasoning.

Karahan and Roehrig (2017) conducted a multiple case study in which they demonstrated the diverse and sometimes inconsistent ways twelve students expressed SSR when they were instructed about SSI focused on the erosion and pollution of the Minnesota River. The students recognized various factors that contributed to the complexity of the SSI, which included the involvement of different stakeholders, conflicting interests of upstream and downstream communities, and economic consequences of the proposed resolutions. Karahan and Roehrig's (2017) study also indicated that the position students took concerning the Minnesota River SSI appeared to influence their ability to engage in perspective-taking. For example, students taking a biased position tended to explain the issue from a single perspective (e.g., from scientific studies or personal experiences) while other students who took a neutral position were able to explain the issue from multiple perspectives. When providing statements about scientists' research, the students recognized that ongoing inquiry into the water quality issue was being conducted. However, the students also indicated that the scientists' findings concerning sediment and 
chemical loads in the river were conclusive and would not change through future research. Lastly, skepticism exhibited by the students varied based on the informational sources they encountered. For example, students were more skeptical about nonscientific information, such as that shared by environmental and economic interests, than they were about scientific reports. However, students also recognized that scientific information had the potential to be biased based on sources of funding and whether the scientists had vested interests.

Recently, Kinslow, Sadler, and Nguyen (2018) sought to determine how students' SSR varied after completing a six week SSI-oriented field ecology class. Each student completed the Quantitative Assessment of SocioScientific Reasoning (QuASSR; Romine, Sadler, \& Kinslow, 2017), an SSR assessment approach that uses open-ended scenarios. In this study, the scenario focused on ground water quality associated with a proposed ethanol plant, and was administered to students before, immediately after, and six months following the course. Results indicated that the students' QuASSR scores significantly increased across the SSR dimensions of complexity, perspectivetaking, and inquiry, and those significant increases persisted after six months. While no significant differences were observed in skepticism through the QuASSR assessment, Author did find qualitative evidence of skepticism in student course work, which suggested that students' skepticism was limited and context specific. Importantly, Kinslow et al. (2018) empirically demonstrated through the students' qualitative responses that clear overlaps exist across the four SSR constructs and the NAAEE environmental literacy competencies (2011). Therefore, this work bolsters the justification for promoting SSR as a crucial component of resolving SSI.

\title{
Socioscientific Reasoning for Environmental STEM Literacy
}

While the overwhelming majority of SSI research has focused on learners and teachers of science, a need to broaden this field of work to include learners and teachers of all STEM disciplines exists. Zeidler (2016 p. 17) sums up this compelling argument well:

\begin{abstract}
STEM-based programs, at the present, tend to be conceived and entrenched in silos of science, technology, engineering and mathematics; attention is then directed at crosscutting connections among those areas. The problem at-hand is that doing so creates a stilted understanding of scientific literacy. Moreover, the restrictive nature of STEM silos effectively removes it from the cultural milieu of ordinary experiences by ordinary students. The overlap of STEM silos are typically focused on aspects of scientism that perpetuate unreflective narratives and undue confidence in public policy derived from scientific programs steeped in objectivity.
\end{abstract}

This historical "siloed" approach to STEM works against the goals of environmental literacy and the effective resolution of SSI, which requires individuals to reflectively consider the complexity of those issues across multiple perspectives, engage in skepticism and ongoing inquiry, and recognize the affordances and limitations of science in relation to other knowledge bases. Therefore, an SSR approach should not only be promoted among science learners and teachers, but among the teachers and learners of all STEM fields in the interest of weaving a common thread across STEM topics, enhancing environmental literacy, and encouraging civic participation and environmental sustainability. More specifically, we advocate that knowledge bases should be promoted among all STEM teachers and learners that demonstrate the overlap that exists between the SSR constructs and the NAAEE environmental literacy competencies (NAAEE, 2011) that has been outlined by others (e.g., Kinslow et al., 2018). For these reasons, SSI serves as a viable means for engaging teachers' and learners' SSR across the STEM fields in a manner that promotes a functional environmental STEM literacy.

\section{PURPOSE OF STUDY}

We posit that promoting SSR among STEM learners represents a potentially productive approach for environmental education. The SSR construct reflects contemporary perspectives on what will be necessary to make progress toward environmental literacy, and recent studies on student SSR competencies and learning suggest that featuring SSR as a goal for STEM teaching is a viable strategy. However, as a field we know very little about teachers' SSR. We do know that that teachers often struggle to recognize the complexities and ethical aspects of contentious environmental issues (Gayford, 2002). Additionally, we know that STEM teachers are often forced into single subject orientations that heavily emphasize the specific content and methods of an individual field (Schleigh, Bossé, \& Lee, 2011). In order to make progress toward a more effective integration of SSR in STEM education for the promotion of environmental literacy, we need to better understand how STEM teachers engage in SSR. Given the historic separation of STEM disciplines, it will also be helpful to explore ways in which teachers from different STEM disciplines differ with respect to their SSR competencies. These findings, in turn, will provide new insights important for informing efforts to prepare STEM teachers for promoting SSR among their students. Therefore, the purpose of this study was to better understand the SSR exhibited by teachers from two STEM fields, science and mathematics, as they considered a regionally relevant SSI. The following question guided our research: 
How do secondary mathematics and science teachers exhibit SSR when engaging in a regionally relevant SSI?

\section{METHODS}

\section{Participants}

Participants were 21 secondary science (13) and mathematics (8) teachers, from diverse districts, including rural, suburban, and urban, in a Midwestern U.S. state, who were engaged in a professional development program focused on STEM literacy practices. Nine of the science teachers were Caucasian females, three were Caucasian males, and one was a black African male. All eight of the mathematics teachers were Caucasian, four male and four female. Having recognized the call from reform-based documents to contextualize science and mathematics instruction in real-world contexts and the challenges that entailed, these teachers actively sought professional development that would better prepare them to integrate STEM disciplines and literacy practices. All of the teachers voluntarily participated in this investigation by completing an instrument designed to measure SSR while they engaged in the negotiation of a regionally relevant SSI.

\section{The Professional Development Experience}

The professional development was hosted at a large, Midwestern research university as part of an Improving Teacher Quality Grant. Teams of mathematics and science teachers, ranging in size from two to six, from partner districts serving high need communities participated. The complete PD experience extended over the course of two years with four face-to-face workshops per year and in-school coaching. The central focus of the PD was integration of literacy and STEM disciplinary ideas across student learning experiences. Environmental SSIs were introduced as a platform for integrating the STEM disciplines and literacy practices. During the face-to-face sessions in year one, teachers participated in several learning experiences related to environmental issues. For example, participants read portions of an international consensus report on climate change and discussed 1) representations of evidence in the report, 2) why interpretations of the report had been politically controversial, and 3) their own personal perspectives on actions that should be taken in response to climate change. Data collected for this study occurred at the beginning of the second year of PD. The idea of SSR as a learning objective with examples of student work revealing a range of student competencies was introduced during year two professional development experiences. Therefore, at the time of data collection, teachers had been exposed to SSI as an approach for teaching STEM, but they had not explicitly considered SSR, the subject of this investigation.

\section{Data Collection}

The teachers investigated here read a narrative concerning a problem situation localized in Des Moines, IA, where residents resent having to remove nitrates from their source of drinking water - the Raccoon River. These nitrates enter upstream by way of agricultural runoff, and the city of Des Moines has taken civil legal action against those they feel are responsible for the runoff. Environmental impacts from excessive nitrates can lead to algal blooms and deplete dissolved oxygen that fish and other aquatic life need to survive. Consumption of large concentrations of nitrates via drinking water decreases blood's ability to effectively deliver oxygen to the body. Complicating matters, the Raccoon River nitrates SSI also entails agricultural and urban economics, moral judgments regarding who is at fault, and political decisions behind water policy. Effectively engaging with and teaching about this SSI requires sophisticated SSR skills. After reading about the issue, the teachers responded to several open-ended items as part of a QuASSR assessment that addressed the five dimensions of SSR concerning the Raccoon River nitrates issue (Appendix A).

\section{Data Analysis}

The use of scoring rubrics can increase the reliable scoring of performance assessments such as the QuASSR (Jonsson and Svingby, 2007). We developed and utilized the SSR rubric by expanding an existing three-point scale rubric (i.e., low, medium, and high) that was used in a previous investigation (Kinslow et al., 2018) to an a priori five point $(0-4$ points) rubric, which we felt better assessed participants' abilities to provide sources of each dimension and elaborate or justify those sources to demonstrate their reasoning. In order to achieve the maximum score of four points for each dimension of SSR as indicated by the expanded rubric, the respondent needed to identify two sources of information regarding a particular dimension of SSR, with each source accompanied by an explanation or justification for why that source contributed to that dimension. Using a random sub-sample of teacher and student responses from a broader pool of data collected from administering the prompts to middle and high school students across the state, the rubric was subjected to several iterations of testing and revision until an 
inter-rater reliability of 0.88 was calculated using Cohen's Kappa $(p<0.001)$. Finally, the SSR rubric was used to rate the teachers' responses investigated here. (See appendix B for the SSR rubric).

Excerpts of the teachers' responses are provided to elucidate the different levels of sophistication demonstrated for each dimension of SSR. The excerpts reported were selected so as to account for the range of sophistication demonstrated in the mathematics and science teachers' SSR, including the variety of sources that teachers felt contributed to the complexity of the issue; of information types that warranted further inquiry; of perspectives held by the various stakeholders involved; of quality and bias inherent in SSI information sources and scientists reporting; and of the affordances that science and non-science considerations provided toward the informed resolution of the Raccoon River nitrates SSI. For the purpose of anonymity, each teacher was assigned a pseudonym, which accompanies their excerpted response. Pseudonyms are followed by $(\mathrm{M})$ or $(\mathrm{S})$ to indicate their subject area. For example, John (S) would be indicative of a male science teacher and Sally (M) would indicate a female mathematics teacher.

Knowing whether SSR differences exist among teachers from different STEM disciplines may beneficially inform SSI PD efforts. Therefore, we used Mann-Whitney U tests to augment our descriptions of mathematics and science teachers' SSR abilities across the five dimensions of SSR. Our purpose in doing so was not to seek significance in the traditional sense through using p-values, as the sample size of each group was small (math teachers $n=8$, science teachers $n=13$ ). Moreover, researchers in other fields, such as measurement in medicine, have pointed out the problematic nature of relying on p-values while interpreting results. These issues become apparent for various reasons including that $\mathrm{p}$-values are impacted by varying sample size and fail to indicate magnitudes of difference among compared groups (Perdices, 2017; Sullivan \& Feinn, 2012). Because of these concerns, we looked to use the effect size, as well as the frequency distribution of mathematics and science teachers' responses, as a means for indicating interpretable differences among the two groups of teachers across each SSR dimension. The results of Mann-Whitney U tests reported for each dimension of SSR include $r$ as a measure of effect size (Clark-Carter, 1997), where $r$ was calculated by dividing $Z$ by the square root of $N(r=Z / \sqrt{ } N)$. The percent frequency of mathematics and science teachers exhibiting each level of reasoning for each dimension of SSR can be found in Figure 1. All effect sizes augmenting our interpretation of these frequencies followed Cohen's standard, where .1 represented a small association, .3 a medium association, and .5 a large association (Cohen, 1988).

\section{FINDINGS}

Teachers' responses to the SSI demonstrated a range of sophistication for each SSR dimension. The findings below present the nuanced ways the teachers' responses to the SSI demonstrated each of the five SSR constructs, including differences in the sophistication exhibited in the responses of mathematics and science teachers. For tables that include an exemplar quote for each response level of each dimension of SSR, as well as a description for each level of sophistication within an SSR construct, see Appendix C. Additionally, the frequency of mathematics and science teachers exhibiting each level of sophistication for each of the SSR dimensions can be seen in Figure 1.

\section{Complexity}

SSI are open-ended and multi-faceted, and as a result, they are difficult to resolve. All of the teachers claimed the Raccoon River nitrates SSI entailed complexity to varying degrees of sophistication. A large majority of the teachers investigated here identified general economic implications and financial liability as primary contributors to the complexity of the Raccoon River nitrates SSI. Additional sources of complexity identified by the teachers ranged from generally recognizing the issue's ill-structured nature to specifying human health implications, the need for swift resolution to break historical trends of unrestricted fertilizer usage, and the diverse stakeholder perspectives as to who bore responsibility for resolving the issue. Both the frequency distribution of responses and the effect size suggested that science teachers offered more sophisticated complexity responses than did mathematics teachers (science $M d n=3$, math $M d n=2, U=37.5, p=.276, r=.24$ ) (see Figure 1, Appendix C).

Teachers exhibiting level 1 complexity identified, with no contextual justification, at least one factor that made resolving the nitrates issue difficult. For example, Mark $(\mathrm{M})$ indicated that the issue would be difficult to resolve because "the farmers and the city have legitimate concerns about who should pay for the clean water."

Teachers demonstrating level 2 complexity did so by supporting one source of complexity with an explanation or justification. For example, Tina (S) indicated:

This situation is difficult because you want the best for everyone involved. The farmers are working hard and already paying taxes so you don't want to make them pay more. The city is also doing their best to keep things running well on a limited budget. 
In doing so, Tina (S) highlighted one significant aspect of SSI that make them complex - that proposed resolutions do not equally benefit those involved. Specifically, Tina $(S)$ recognized that resolving the Raccoon River nitrates SSI would be disproportionately costly to farmers and the city of Des Moines.

Teachers exhibiting level 3 complexity were able to identify at least two factors contributing to the complexity of the Raccoon River nitrates SSI. Furthermore, these teachers' responses elaborated or justified how one of those factors made the SSI complex. One of those teachers was Sally (S):

\begin{abstract}
The socio-economic dynamics are complex. Farmers use heavy fertilizers to make more money. If the farmers have to take longer to grow crops, then they will raise prices and consumers will pay. . If the Water Works pays to clean this up, they will pass on that cost to the citizens. . But many can't afford it or simply don't want to spend their money on something they used to get much cheaper. Unfortunately, many people are not too concerned about environmental issues - even when it IS impacting their own health and well-being.
\end{abstract}

In the excerpt above, Sally (S) explained the complexity of the Raccoon River nitrates SSI through elaborating how interrelated economic factors such as the ways farmers' fertilizer use impacts the costs of produce and water quality treatments - which will be passed on to consumers. As a second source of complexity, Sally (S) noted without justification or elaboration that people generally lack concern about environmental issues that can impact their health.

Finally, teachers exhibiting the most sophisticated (level 4) reasoning about the complexity of the Raccoon River nitrates SSI identified at least two sources of complexity through explanation or justification. For example, Jen (S) explained that:

There are many factors which can contribute to the high nitrate levels. These of course mainly stem from the farmers but the farmers and their yields are important not just for their own benefit but for the larger community as well. They can make many changes to their practices that can help in varying degrees, but each change must be evaluated for its effectiveness for helping resolve the water issue as well as the cost-profit implications it may have for the farmers. The utility company will also have to factor in many concerns including cost. Cost may include the need for facilities and employees. These changes need to be evaluated for their long-term feasibility.

Jen's (S) response exhibited sophisticated reasoning concerning the complexity of the issue through recognizing and justifying first, that a number of sources - not just farmers - are contributing to the problematic nitrate levels. Second, Jen (S) explains that water-quality treatment effectiveness and economic concerns experienced by farmers and utility companies are long-term complexities associated with the Raccoon River nitrates SSI. By identifying and justifying multiple sources of complexity, Jen (S) exhibited a sophisticated level of complexity.

\title{
Inquiry
}

The multi-faceted uncertainty surrounding SSI suggests that understanding the issue and successfully resolving it necessarily requires ongoing inquiry. All of the teachers indicated that they would need to conduct additional queries before coming to a resolution about the Raccoon River nitrates SSI. While the teachers sought a variety of information types, the sources of information most often desired concerned economic and scientific and technological facets of the SSI. Desired economic information included financial ramifications of reducing nitrates on farmers' profit margins and Des Moines citizens seeking to implement water treatments. Information pertaining to science and technology sought by the teachers concerned best farming practices (e.g., fertilizer use and crop rotation), nitrate loads being contributed from agricultural and non-agricultural sources, and established and novel technologies to mitigate nitrate run-off and treat water. Other lesser-sought types of additional information by the teachers included that which was historical (e.g., past farming practices and demands), political (e.g., Clean Water Act regulations and state and city subsidy programs), and human and ecosystem health related (e.g., whether nitrates are safe for human consumption or have unintended benefits and consequences for natural flora and fauna). Both the frequency distribution of responses and the effect size suggested that science teachers offered more sophisticated inquiry responses than did mathematics teachers (science $M d n=2$, math $M d n=1, U=44.5, p=.554$, $r=.13$ ) (see Figure 1, Appendix C).

Teachers that exhibited level 1 inquiry identified one area of need for further inquiry, but failed to justify or explain how information from that query would help resolve the Raccoon River nitrates SSI. For instance, Peter (M) stated that he needed to know "What the Clean Water Act is [and] how much it would cost each farmer to remove nitrates from the water."

In the quote above, Peter (M) sought information about the Clean Water Act and treatment costs without indicating how having that information would enhance their ability to resolve the issue. 
Teachers demonstrating level 2 inquiry exhibited more sophistication than level 1 inquiry responses because they explained or justified how that area of further inquiry would aid their decision-making regarding the Raccoon River nitrates SSI. For instance, Mark's (M) response links the information that would result from his further inquiry to his ability to resolve the SSI:

I would like to see some figures on what the impact would be for the farmers if they were asked to pay to clean the water. What impact would that have on their profitability? If the cost were borne on the citizens, how much of an impact would it have on their water bill? Since the whole state benefits from the corn industry it would seem logical to assess everyone in the state. I would want to know the population and what increase they would have on their bill.

Mark's (M) response above indicates a desire to know more about how the financial responsibility would be allocated across the stakeholders impacted by the Raccoon River nitrates SSI and elaborates on the importance of obtaining that information for resolving that issue.

At the highest levels of inquiry sophistication, the teachers included at least two areas of further inquiry into the Raccoon River nitrates SSI and provided one (inquiry level 3) or more (inquiry level 4) contextual explanations or justifications how those inquiry sources helped resolve that SSI. For instance, Daisy (S) exhibited level 4 sophistication in her response:

\begin{abstract}
Scientific data needs to be provided to show that a change in farming practices including improved drainage techniques and the use of improved technology by the Des Moines Water Works would actually be successful in removing the dangerous nitrates. Treatment facility upgrades might improve the water quality in the area but how much of that problem would have actually been caused by farming practices?... Additional information is [also] needed about the Federal Clean Water Act to evaluate the basis for the Des Moines Water Works' claim that the Raccoon River issue should be regulated by the Act. If the issue does fall under the requirements of the Act, how would that affect the party responsible for cleanup and future management of agricultural nitrates into the Raccoon River?
\end{abstract}

Daisy's (S) response highlighted two areas of further inquiry she perceived were necessary before resolving the Raccoon River nitrates SSI. First, Daisy (S) justified that more scientific information about agricultural practices and technology that would inform the manner in which the farmers and citizens of Des Moines might contribute to the resolution of the issue. Additionally, Daisy (S) sought political information about the Federal Clean Water Act to clarify whether it had any bearing on the Raccoon River nitrates SSI, which would necessarily affect the designation of responsibility for cleanup.

\title{
Perspective-Taking
}

SSI are multifaceted and as such, may be perceived differently by different stakeholders. As a result, successful resolution requires consideration of diverse and oftentimes, opposing viewpoints. In this study, teachers were tasked with taking perspectives concerning a proposed resolution that required the farmers to voluntarily upgrade their agricultural practices and the citizens of Des Moines to upgrade the technology used at their water treatment facility. The teachers exhibited a range of sophistication in terms of their perspective-taking abilities, from those that appeared unable to engage in perspective-taking to those who presented detailed elaborations about the perspectives of those impacted by the Raccoon River nitrates SSI (e.g., "Big Corn farmers in Western Iowa, citizens of Des Moines). Both the frequency distribution of responses and the effect size suggested that science teachers offered more sophisticated perspective-taking responses than did mathematics teachers (science $M d n=4$, math $M d n=3.5, U=39, p=.277, r=.24$ ) (see Figure 1, Appendix C).

At the lowest levels of perspective taking (i.e., level 0), teachers may appear unable to take another's perspective or provide perspectives or judgments that were irrelevant (e.g., their own perspective) and inconsistent with perspectives likely exhibited by those impacted by the Raccoon River nitrates SSI. For example, Peter (M) was unable to take the perspective of either the "Big Corn" farmers or the citizens of Des Moines, responding "I have no idea" to questions about how each stakeholder would respond to the proposed resolution. Holly (S), projected her own perspective upon those impacted by the resolution, indicating "I think that the residents should be happy that both parties have to help solve the problem".

Teachers exhibiting level 1 perspective taking were able to present a perspective consistent with one stakeholder, but provided no explanation or justification for doing so. For instance, regarding the perspective of “Big Corn" farmers, Molly (M) stated: 
If ["Big Corn" farmers] are smart and will do the right thing, they will understand that the farmers will have to help in the responsibility of cleaning up the pollution. [The concerned citizens of Des Moines] will want the farmers to take care of all of it.

Molly (M) exhibited level 1 perspective-taking in that she was able to take the perspective of the citizens of Des Moines in suggesting that they would want the farmers to foot the bill for the cleanup. However, Molly (M) inaccurately characterized the farmers' response to the proposed solution by projecting her judgment upon them as to what the right response for them to have would be.

Teachers demonstrating level 2 perspective-taking exhibited more sophistication than level 1 responses by explaining or justifying the perspective they provided in response to the proposed resolution. Mike's (S) response is representative of level 2 perspective-taking:

I think [the "Big Corn" farmers] would balk at it. They would not like the idea of having to invest in new equipment or practices that could possibly reduce their profit margin. Chances are the new practices will come at a financial cost or will take more time from the farmers, thus making them work more while possibly even earning less. No matter what happens, the resident of Des Moines are going to pay. If nothing is done regarding the polluted river, the city will pass on the costs on their customers' water bill. If the farmers have to improve their farming practices (no doubt at a financial cost to them), they will raise the prices on their delicious corn.

Here, Mike (S) accurately justifies the farmers' negative viewpoint toward incurring financial costs due to resolving the Raccoon River nitrates SSI. However, rather than offering a concerned citizen perspective, Mike (S) makes a judgment as to what he felt the outcome of the proposed resolution would be.

Most of the teachers demonstrated the sophisticated forms of perspective-taking by presenting view-points consistent with both the "Big Corn" farmers and Des Moines citizens and explaining or justifying one (level 3 perspective-taking) or both (level 4 perspective-taking) perspective(s). For instance, Yulia's (S) response exhibited level 4 perspective-taking.

Farmers might be resistant just because they see success (net profit) from their current processes and fear that changing the way they do things will reduce their net profit. "If it ain't broke, don't fix it." They may also view the changes as being disruptive to their lifestyle, as either a time demand or a demand for new ways of thinking. They may also view their personal economic success as being more important than ecological conscientiousness. Des Moines residents would probably be happy with the suggestion that the farmers upgrade their practices because it doesn't increase their costs at all. However, they may not be happy with the suggestion that the utility company pay an unknown sum of money for expensive equipment to remove more nitrates because that cost will be passed on to them.

Here, Yulia (S) indicated that the farmers would be opposed to the plan because it would be costly and result in a lifestyle change, and that making money was more of a priority than was behaving in an ecologically appropriate manner. She also indicated that Des Moines citizens would be happy to see farmers having to contribute to the resolution of the SSI, but would not be happy that the utility company, and thereby the citizens of Des Moines, would also be held financially responsible.

Other level 4 responses provided by a few teachers advocated that lesser oppositional and confrontational perspectives could occur among the farmers and Des Moines' citizens seeking to resolve the Raccoon River nitrates SSI. For example, Tina (S) responded:

Big Corn:

I feel like [the "Big Corn" farmers] would be open to this idea, doing something voluntarily is better than being forced to do something. Plus if you start to get rid of a problem early then it might cost less than waiting until the problem is extreme. Anytime you can keep the government out of your business or off your land the better. Stay off the radar. ... I don't know if the Des Moines Water works would be in favor of upgrading their technology. I am sure that would cost a lot. They might be willing to do small parts at a time if they can. But upgrading their technology may not take care of the ultimate problem. It will help but what about the areas before Des Moines, their water will still have a higher input of nitrates.

In her response above, Tina (S) indicated that the farmers may voluntarily acquiesce to proposed resolutions rather than be forced into more intrusive ones through government intervention. Responses like Tina's (S) suggest that a single perspective might not always define a stakeholder group and that varied perspectives are likely to be present among individuals within the communities of "Big Corn" farmers and the citizens of Des Moines. However, the justification of one perspective or another is key to supporting its validity. 


\section{Skepticism}

Resolving SSI effectively requires negotiating multiple scientific and non-scientific sources of information. However, because informational sources about SSI are potentially biased, it is necessary to exhibit skepticism when drawing from those sources. In this study, we sought to better understand the level of skepticism exhibited by teachers concerning informational sources about the Raccoon River nitrates SSI. More specifically, we asked the teachers to separately consider SSI informational sources broadly (i.e., considering non-scientific and scientific sources) and scientists' reporting (i.e., research reports and peer reviewed work), specifically.

Skepticism regarding broad SSI information sources. Because a number of SSI information sources of varying quality and bias exist, it is imperative that individuals seeking to understand and successfully resolve SSI exhibit skepticism when seeking information concerning the SSI. Teachers exhibited a range of sophistication in their skepticism when asked to consider whether SSI information sources, including interviews with farmers and Des Moines citizens, social media, blog, and Wikipedia posts, and research studies published in reputable journals. Both the frequency distribution of responses and the effect size suggested that science teachers exhibited more sophisticated skepticism concerning SSI information sources than did mathematics teachers (science $M d n=3$, math $M d n=1.5, U=36, p=.228, r=.26$ ) (see Figure 1, Appendix C).

Teachers exhibiting the least sophisticated skepticism (i.e., level 0), indicated that all informational sources about the Raccoon River nitrates SSI were equally good or failed to indicate a difference in the sources. For instance, Amy (M) stated that "these sources of information together would all be high quality" but failed to provide for any differences between the sources in terms of quality.

Teachers exhibiting level 1 skepticism regarding SSI information sources provided one difference in the quality of the three sources of SSI information. These individuals generally indicated that "Big Corn" region farmers' and Des Moines citizens' interviews would present biased and opinionated information, or that research studies would demonstrate a higher degree of reliability, but failed to justify why they felt that way. One such response was provided by James (S), who stated:

Interview with farmers and residents will be biased toward one side or the other. Social media, Blog, and Wikipedia posts are not reliable sources of information. Research-based studies that are quantifiable are the most reliable sources.

Here, James (S) indicates that interviews with the stakeholders would be biased, that social media would be unreliable, and that research-based studies would be the most reliable, but fails to explain why.

Teachers who exhibited Level 2 skepticism regarding SSI information sources provided one difference between the sources in terms of their quality as well as a justification for that difference. For example, Mark (M) indicated that:

The social media and blogs might not have factual data presented. My perception of the blog and social media would be more of an outlet of frustration or venting and not explicitly factual data. The research studies would provide, or at least should, provide scientific data about the issue in a more or less unbiased way.

Above, Mark (M) noted a difference in the factual nature of social media and research studies by highlighting that data driven research would exhibit less bias than blog posts that often serve as an outlet for emotional venting.

Teachers demonstrating the most sophisticated forms of skepticism highlighted multiple differences between the sources of information and provided elaboration as to how one (level 3 skepticism) or more (level 4) of the differences were important. For instance, Jerry $(\mathrm{M})$ offered a level 4 skepticism response by stating:

\footnotetext{
Each source provides a specific viewpoint. Interviews with Big Corn farmers E residents of Des Moines ... would give the opinions and subjective feelings of both primary sides of the issue and would be a way to help determine both how and why each side feels the way that it does. Social Media, Blog, and Wikipedia posts about the issue. . . would provide similarly biased information but also bring in opinions of people that aren't directly connected to the issue at hand, giving some outside opinions on how the arguments from both main sides may affect Iowa as a whole, or at least on a grander scale that *just* Des Moines [citizens] vs. Big Corn [farmers]. Research studies published in reputable science journals [with] actual data . . would be invaluable in terms of making a true decision. However, numbers aren't the entire story - for example, a cost-sharing measure for filtration undertaken by the Farming Cooperative may affect smaller farms with lesser profit margins more than larger farms. While the numbers and data and research are absolutely needed, they don't paint the whole picture.
} 
In his response, Jerry $(\mathrm{M})$ highlighted the nuanced differences in the characteristics (e.g., biased nature, veracity) of multiples sources of information including social media posts, Wikipedia, and scientific journals. Furthermore, he deliberated strengths and weakness of each - integral to a skeptical frame of mind.

Skepticism regarding scientists' reporting. If position-taking and decision-making when seeking to resolve SSI is to be informed, then an understanding of how science works, including biases inherent to the discipline, is requisite. The teachers in this study exhibited limited skepticism when considering reports given by scientists hired by the farmers and those hired by the citizens of Des Moines concerning the Raccoon River nitrates SSI than when considering SSI informational sources more broadly. Both the frequency distribution of responses and the effect size suggested that science teachers exhibited more sophisticated skepticism concerning scientists' reporting than did mathematics teachers (science $M d n=2$, math $M d n=2, U=42.5, p=.356, r=.20$ ) (see Figure 1, Appendix C).

Teachers exhibiting the least skepticism (i.e., level 0) suggested that the reports provided by the farmers' scientists' and the citizens' scientists would be similar. For example, Eva (M) indicated that "[both reports] are given from scientists, so the information would be similar." Characteristic of other teachers providing level 0 skepticism responses, E (M) neglected to recognize that funding sources can influence how scientists' findings are reported.

Teachers exhibiting Level 1 skepticism identified one way that the scientific reports stemming from the disparate funding sources of the Des Moines Water works and from the farmer's cooperative would be different. Among some of these teachers' responses it was clear that they identified the reports would reflect the different agendas of the "Big Corn" region farmers and city of Des Moines. Other teachers, such as what is reflected in Mark (M)'s following statement, indicated the data presented in the reports might be different. "The reports would be different to show data that would reflect positively for the party concerned." This quote from Mark's (M) exhibits level 1 skepticism because it suggests that the scientists' reports would differ because the data selected for those reports supported the funding stakeholder's position.

Most of the teachers' responses about the scientists' reports exhibited level 2 skepticism by identifying and elaborating one way that the reports would be different. All of those teachers indicated that the scientists' reports would subjectively favor their funding stakeholders (i.e., the "Big Corn" region farmers' cooperative or the Des Moines Water Works). For example, Sally (S) recognized that:

Both are scientists who have been hired by organizations with a clear agenda. Organizations aren't going to hire a scientist that's not willing to say what the organization wants them to say. In both cases, the scientists are receiving money from stakeholders and are not objective parties.

Sally's (S) response appears to identify that the reports would certainly reflect the interests of the funding stakeholders, and explains that because of this the reports would lack objectivity. Other teachers indicated the reports maybe written to appeal to more emotive considerations, thus bolstering each stakeholder's position. Peter's (M) response below reflects how the scientists' reports may differ in non-scientific and emotive ways.

The Cooperative scientists ... may accuse the Water Works scientists of conspiring against the humble farmer and taking advantage the farmers' noble, yet unsophisticated, profession. The Water Works scientists will predict mutant babies will soon be born, and this is most certainly attributable to the toxic amounts of the horrific nitrates that are being dumped into the water by farmers that are, at best stupid, and at worst evil.

In a sense, Peter's $(\mathrm{M})$ response appears to caution against the ways that scientific reports can be perceived as emotively charged and biased when special interest groups with an agenda fund them.

None of the teachers identified ways the scientists' reports would differ other than that they would be biased toward supporting their funding stakeholder group, such as error inherent to science practice, poor methodology in the research, or misinterpretation of results. As such, no teacher was scored above level 2 skepticism (i.e., level 3 or 4$)$.

\section{Affordances of Science and Non-science Considerations}

On one hand, science provides several affordances toward informed resolution of SSI to include providing empirical, mechanistic and predictive explanations about SSI related natural phenomena. Furthermore, science provides guidance regarding how SSI related natural phenomena might be manipulated through technological, engineering, or human behavioral approaches. On the other hand, science is limited in several ways regarding the resolution of SSI in that effective resolution requires consideration of non-scientific concerns, such as morality, sociocultural and economic factors, equity, and distributive justice. Here we present the extent that the investigated teachers' recognized the affordances that science and non-science considerations exhibit in relation to resolving the Raccoon River nitrates SSI. 
Affordances of science. SSI, such as the Raccoon River nitrates SSI, are undergirded by science and thus, exhibiting sophisticated reasoning about the affordances of science regarding SSI is requisite to their resolution. The teachers' responses regarding how science could help resolve the Raccoon River nitrates SSI varied from those indicating that science should not play a role in that resolution, to those explaining multiple ways science would contribute to that resolution. Both the frequency distribution of responses and the effect size suggested that science teachers exhibited more sophisticated reasoning about the affordances of science than did mathematics teachers (science $M d n=2$, math $M d n=1, U=31, p=.110, r=.35$ ) (see Figure 1, Appendix C).

Teachers providing a level 0 response failed to indicate ways that science could contribute to the resolution of the Raccoon River nitrates SSI. For example, Peter (M) suggested that:

\title{
The problem here is not scientific. Everybody agrees nitrates are in the river, and are harmful. The problem is political - who is going to take the responsibility for fixing it? This is not part of what scientists are supposed to do.
}

In the quote above, Peter $(\mathrm{M})$ recognizes that science is limited in its ability to resolve the Raccoon River nitrates SSI, but fails to indicate any aspects of issue resolution that are afforded by science.

Unlike Peter (M), most of the teachers were able to offer at least one way that scientists could contribute to resolving the issue (level 1 affordances). For example, Lilly (S) suggested that scientists could "provide more education to all stakeholders". Those teachers that exhibited a more sophisticated understanding of the affordances of science offered justification for the contribution of science (level 2 affordance). Holly (S) was one of those teachers.

\begin{abstract}
Scientists are problem solvers and can possibly figure out a better and more effective way to deal with the nitrates in the water. Maybe there is something that can be put into the water to break down the nitrates in a more effective way.
\end{abstract}

Holly (S) exhibited level 2 affordances of science reasoning by identifying and explaining one way that science affords resolution of the Raccoon River nitrates SSI.

At the highest levels of sophistication, some teachers were able to identify at least two ways science could contribute to resolving the Raccoon River nitrates SSI and elaborate on how one (level 3 affordances) or more (level 4 affordances) of those ways that science could contribute to that resolution. For instance, some recognized scientists as experts who could educate the public or offer science explanations, such as the science behind water filtration or why some nitrogen was not being taken up by the plants or retained in the soil. Others assumed the scientists could provide options for fixing the problem, such as models that have worked in other locations and evidence-based alternatives to improve the water quality and farming practices. Tori (S) provided such a response, and touched on multiple affordances with elaboration (level 4 affordances):

\begin{abstract}
[Scientists] could explain the complexities of the issue to all stakeholders, describing the importance of nitrates to high crop yield, how runoff and water pollution happens, and how nitrates can affect people when ingested. They can also provide unbiased data and explain what the data means. Scientists could also help develop technologies and practices that could help prevent fertilizer runoff and remove nitrates from drinking water.
\end{abstract}

Here, Tori (S) acknowledged that science offers much toward the resolution of the Raccoon River nitrates SSI. She noted that scientists can provide independent reporting and explain complex phenomena to stakeholders (e.g., farmers and Des Moines residents) regarding that SSI such as the benefits and consequences of nitrates use. Moreover, she indicated scientists can help resolve the Raccoon River nitrates SSI through developing fertilizer runoff mitigation and water quality treatment procedures.

Affordances of non-science considerations. Negotiating and successfully resolving SSI necessarily requires reasoning about the non-science considerations of the issue (e.g., cultural, political, ethical, etc.). The teachers' responses regarding how non-science considerations could help resolve the Raccoon River nitrates issue varied from those indicating ignorance to those explaining multiple ways that non-science considerations would contribute to issue resolution. Both the frequency distribution of responses and the effect size suggested that science teachers exhibited more sophisticated reasoning about the affordances of non-science considerations than did mathematics teachers (science $M d n=2$, math $M d n=2, U=39, p=.328, r=.21$ ) (see Figure 1, Appendix C).

Representing those demonstrating level 0 views about the affordances of non-science considerations for resolving the Raccoon River nitrates SSI, Molly (M) responded to this prompt with a simple "don't know." Teachers who identified at least one way non-science consideration contribute to SSI resolution but did not elaborate exhibited level 1 reasoning about the affordances of non-science considerations. For example, Eva (M) indicated that "the impact that the additional cost would have on the farmers' livelihood" was a non-science consideration that would contribute to the resolution of the Raccoon River nitrates SSI, though she did not explain how it would 
do so. Teachers exhibiting level 2 reasoning largely provided economic considerations with a dedicated focus to how those non-scientific considerations would contribute to the resolution of the Raccoon River nitrates SSI. For instance, Mark (M) elaborated in his level 2 response.

As with all issues there is a financial impact that should be looked at by residents and city officials. The cost of the cleanup or the implementation of better farming practices could be cost prohibitive and strategies should be discussed by all concerned to choose the best for all involved.

Through his response, Mark (M) rightly identified the financial implications regarding resolving the Raccoon River nitrates SSI as an important non-science consideration, and justified doing so by explaining that fiscal accountability would be a limiting factor in resolving the issue. Jerry $(\mathrm{M})$ also exhibited level 2 reasoning concerning the economic considerations, specifically.

\begin{abstract}
How would the cost-sharing actually affect the farmers, or city residents, on an individual level? ... The reality of improving farming techniques may drive smaller farms out of business. Should the farmers not having to foot the bill occur, this could potentially drive public opinion against them potentially leading to a backlash where people go out of their way not to do business with them, affecting those farmer's profits. Should the farmers have to pay for the filtration, they may decide to charge more for their crops (assuming of course that the price for crops isn't already set by the government) or perhaps their services and therefore pass that cost back to the city residents anyway.
\end{abstract}

Jerry's (M) reasoning about the economics of Raccoon River nitrates SSI resolution was quite sophisticated. He noted that the cost of improving farming practices might shut down small farms or raise prices for individuals outside the counties involved who buy those crops. Jerry $(\mathrm{M})$ also touched on the potential financial backlash that might occur if farmers were not held accountable and the citizens boycotted their products. However, Jerry's (M) reasoning about non-science considerations was limited to the economic realm.

Teachers who identified at least two ways that non-science considerations contributed to SSI resolution with explanation for one or all of those ways were respectively rated as demonstrating level 3 and 4 reasoning about this dimension. Those exhibiting the most sophisticated reasoning about the affordances of non-science considerations toward SSI resolution described economic implications, available technology, politics, ethics, environmental concerns, and the quality of life for farmers' families or those suffering the ill-effects of nitrate-laden drinking water. For instance, Sally $(S)$ exhibited level 4 non-science considerations by elaborating on both economic and political non-science concerns, though there was significant overlap:

It is important to consider the economics involved and the role government plays in creating (and hopefully solving) these problems in the first place. In the current system, it's the farmers' benefit to crank out as much corn as they can in as little times as possible. That is the current economic incentive because the government subsidizes corn and soybean production. Instead of yield, perhaps the government should incentivize sustainable practices that will be better for everyone in the long term.

In her justification, Sally (S) touched on the economic implications that underlie the issue and its potential resolution, but also explained that political ramifications resulting from government interference and incentives will have to be addressed, if the issue is to be resolved.

\title{
DISCUSSION
}

Over recent decades, SSI, across local and global contexts, have increased in severity and magnitude. Supporting the development of environmental literacy through STEM education has been one way to address these SSI with the purpose of helping people to understanding and resolve these complex problems as part of an informed citizenry (Owens, Sadler, \& Zeidler, 2017). However, while promoting an understanding of the STEM concepts that undergird SSI is certainly requisite, doing so alone is insufficient. Rather, contemplation of the nonscience aspects of SSI, such as the associated sociocultural perspectives, economics, politics, and morality are also requisite to the successful resolution of those issues. For this reason, we agree with others (e.g., Fountain, 1998; Zeidler, 2016) that the current "siloed" approach to STEM education, which elevates STEM content while failing to promote non-scientific considerations of these issues, is highly problematic and perpetuates the issue of environmental illiteracy and issues disengagement. In other words, historical approaches to environmental education have encouraged high levels of science content understanding. However, concerns have been voiced that those approaches have done so in a manner that eschews more humanitarian themes and fosters detached and uncritical attitudes of scientism and technocentrism, which can lead to public inaction regarding SSI resolution (Herman \& Clough, 2017; Herman, 2018). 
To promote a more holistic form of environmental literacy, we proposed SSR as a way of SSI engagement that teachers and students can use alongside their understanding of STEM concepts in order to stake informed positions concerning SSI and reason through promising resolutions (Kinslow et al., 2018). Through engaging in SSR, teachers and students are able to consider environmental issues through the lenses of complexity, perspective taking, inquiry, skepticism, and the affordances provided by scientific and non-scientific bodies of knowledge. Of course, effective SSI engagement requires much more than SSR. SSI resolution requires a bevy of characteristics such as knowing and using the nature of science, empathetic concern, and sociocultural awareness (Herman, 2018).

We take the position that STEM teachers must be prepared to be able to engage in and model SSR if they are to be expected to help their students develop similar reasoning skills as a part of a robust STEM literacy. As a first step toward preparing teachers to do this, we sought to better understand the SSR that was exhibited across science and mathematics when engaging in a regionally relevant SSI of agriculturally sourced nitrates in the Raccoon River. In this study, the science and mathematics teachers exhibited a wide range of sophistication regarding the different dimensions of SSR. Specifically, the teachers generally exhibited sophisticated perspective-taking regarding the different stakeholders involved in the Raccoon River nitrates SSI, but struggled to recognize the need for ongoing inquiry regarding the SSI or the affordances of science towards its resolution. Though literature regarding teachers' SSR remains scant, a number of studies offering insight into students' SSR have indicated considerable variation in their abilities to reason about SSI with sophistication. For example, Sadler and colleagues (2007) found sixth grade students to exhibit a significant degree of variability in the sophistication of their responses across SSR dimensions concerning two different environmental issues, water quality problems and pollution from energy production. Those students tended to exhibit sophisticated reasoning concerning perspective-taking while struggling to recognize the complexity of issues and their need for ongoing inquiry. Similarly, Simoneaux and Simoneaux (2009) found students to recognize a number of aspects that contributed to the complexity of an SSI concerning the reintroduction of bears to the Pyrenees, such as environmental and socio-economic concerns. However, these individuals exhibited minimal consideration of stakeholder viewpoints, yet engaged in high levels of skepticism concerning scientific data mentioned in press reports. Kinslow and colleagues (2018) also found students to exhibit a wide range of some SSR dimensions, including complexity, perspective-taking, and inquiry, but failed to exhibit skepticism concerning the local construction of an ethanol plant in an ecologically sensitive area. Though teachers are likely to have had a significantly larger degree of STEM coursework and life experience than the students they serve, teachers also exhibited diversity in the sophistication of their SSR, and thus, could benefit from professional development directed at their development of SSR and ability to engender SSR in the students they serve. Given the wide range of SSR exhibited among students in past research, and among the teachers in the investigation presented here, such teacher professional developments are necessary if the field seeks to promote widespread engagement of SSI and robust STEM literacy among the public (Owens, Sadler, \& Friedrichsen, 2018).

Additionally, we found initial evidence that across SSR dimensions, science teachers exhibit more sophisticated forms of reasoning than mathematics teachers when engaging SSI. Science education scholars would agree that the SSI context factors into an individual's abilities to reason about them (Sadler et al., 2007; Tytler, Duggan, \& Gott, 2001; Zohar \& Nemet, 2002), not just because of their emotional proximity to the issues (Simoneaux \& Simoneaux, 2009), but also due to the degree the individual possesses disciplinary knowledge that directly informs them of the problem context at hand (Sadler et al., 2007; Sadler \& Donnelly, 2006; Sadler \& Fowler, 2006). Mathematics teachers are generally less likely than their science-teaching counterparts to have learned disciplinary specific knowledge (i.e., science content) relevant to environmental SSI during their professional preparation and practice (Austin, Converse, Sass, \& Tomlins, 1992; Cuadra \& Moreno, 2005; McGinnis, Parker, \& Roth-McDuffie, 1999; Schleigh, Bossé, \& Lee, 2011). For this reason, mathematics teachers may be at a disadvantage compared to their scienceteaching counterparts when reasoning and teaching about SSI.

These results suggest that in order for STEM teachers to develop SSR and be prepared to help their students do so, significant PD experiences are necessary - particularly for teachers unfamiliar with SSI or the science that undergirds those issues. We recognize that "the knowledge and skills that teachers acquire are fundamentally linked to the contexts within which those attributes are introduced and developed" (Frykholm, \& Glasson, 2005, p. 128) and affect the manner in which those teachers practice their craft (Schulman, 1986). Thus, if we are to expect STEM teachers to be able to adequately exhibit SSR to the point that they can engender such reasoning in their students, a concerted effort must be made in professional development settings to break them out of their subject silos and into working relationships with teachers from other STEM disciplines, in the context of SSI, in order to shore up deficiencies in content knowledge and contextual awareness across disciplines (Furner \& Kumar, 2007). Such teacher professional development would not only require STEM teachers to engage in understanding and negotiating SSI with individuals from different STEM disciplines, it includes the collaborative planning of integrated curricula in the context of SSI that also includes reasoning about non-scientific considerations necessary for resolution. 


\section{Limitations of the study}

While teachers participating in this study derived from rural, suburban, and urban landscapes, and of an even distribution across the genders, the sample of teachers was small in number and culturally homogenous with twenty of the twenty-one teachers being Caucasian. Future studies should use a larger more diverse group of teachers as participants as this may yield a wider array of responses to the QuASSR and serve for a more robust statistical analysis - particularly when looking for subgroup differences (e.g., comparing mathematics and science teachers). Additionally, these findings are bound by context where the participants responded to a a single issue concerning nitrates in the Raccoon River. It is not clear how the use of different SSI to engage teachers might affect the way they employ SSR. Lastly, questions could be raised as to exactly why science teachers appeared to express more sophisticated SSR than math teachers. Could it be because science teachers possess deeper levels of science content knowledge as we postulated earlier? Or, could the math teachers have felt less efficacious or motivated to respond to the QuASSR and thus provided more superficial responses? Research directed at better understanding how problem situations that are more or less mathematical or scientific in nature affect mathematics and science teachers' SSR, respectively, is warranted. Furthermore, the underpinning factors beyond familiarity with SSI content that may be associated with how one engages SSR (e.g., interest and other emotive variables) deserve further attention through more in depth qualitative studies.

\section{Implications}

Mathematics and science are logically connected (American Association for the Advancement of Science, 1990; Brown \& Wall, 1976; Bossé, Lee, Swinson, \& Faulconer, 2010), and teachers of both subjects are expected to develop their students' abilities to connect learning to contexts outside of formal classrooms (National Council of Teachers of Mathematics, 2008). Teachers' pedagogical attempts to connect science and mathematics through real world problem situations (e.g., Gainsburg, 2008, p. 199) may appear meaningful on the surface, as they promote content knowledge specific to both disciplines. However, these attempts often fail to deeply integrate the complex exoSTEM content considerations that real world SSI entail (e.g., multiple perspectives). For example, Soucy McCrone and colleagues (2008) describe a scenario where students consider how genetically modified watermelons grown in cubical shapes (as opposed to spherical) would affect the cost of transport between grower and consumer, and note that instructors are often satisfied when their students have "determine[d] what mathematics is relevant for finding a solution, solve[d] the problems, and reflect[ed] on the solution in relation to the original problem context" (p. 39). However, without considering the moral or societal implications of resolving the problem situation (e.g. whether genetic modification is culturally acceptable or how changes to the watermelon's shape and transportation might disproportionally affect the stakeholders involved), such instruction falls short of the brand of STEM literacy envisioned by Balka (2011). In cases such as these, teachers' portrayals of real world SSI and their potential resolution appear bounded and sanitized by discipline specific knowledge and fail to value facets of SSR, such as recognizing the problem's complexity and weighing non-STEM factors, which influence one's ability to successfully evaluate information and resolve SSI. STEM instruction problematized in this fashion is likely to encourage students toward scientistic attitudes, where they wrongly and unquestioningly think that knowledge provided by science and other STEM fields should provide the sole voice for SSI resolution (Zeidler, 2016).

In this study, we found secondary mathematics and science teachers' SSR to be limited in general, and potentially more so for mathematics teachers. We assert that while teachers should certainly be brought together for professional development to share STEM knowledge across disciplines, understanding each other's content is not enough if the goal is to model SSI resolution. Rather, teachers must also engage in reasoning about SSI and integrate SSR into their teaching practice, if they intend for their students to be prepared to evaluate both science and non-science considerations, which is requisite to making informed decision in the real world. Luckily, perceptions of literacy across the individual disciplines share a commonality: that literate individuals employ reasoning to identify and resolve problem situations faced by humankind (Zollman, 2012). Professional development for teachers that is contextualized through problematic situations such as SSI can serve as meaningful opportunities for teachers to move beyond their own discipline-specific silos and participate in interdisciplinary collaborations. These professional development collaborations should attend to the convergences in the content and practices that occur across the multiple STEM disciplines as they relate to SSI, and through those collaborations, position teachers develop and share diverse perspectives and SSR abilities that transcend STEM content knowledge in the interest of providing meaningful instruction in the future aimed at promoting STEM literacy and effective SSI engagement. The findings herein, along with the scenario and accompanying scoring rubric, serve to provide both an initial glimpse at mathematics and science teachers' reasoning about a regionally relevant SSI, and exemplars to aid in the design and assessment of professional development and instruction targeted at the enhancement of SSR. 


\section{REFERENCES}

American Association for the Advancement of Science [AAAS]. (1990). Science for all Americans. New York: Oxford University Press.

Balka, D. (Summer, 2011). Standards of mathematical practice and STEM. Math-Science Connector Newsletter. Stillwater, OK: School Science and Mathematics Association.

Barab, S. A., Sadler, T. D., Heiselt, C., Hickey, D., \& Zuiker, S. (2007). Erratum to: relating narrative, inquiry, and inscriptions: supporting consequential play. Journal of Science Education and Technology, 19, 387-407.

Bossé, M. J., Lee, T. D., Swinson, M., \& Faulconer, J. (2010). The NCTM Process Standards and the Five Es of Science: Connecting Math and Science. School Science and Mathematics, 110(5), 262-276. https:/ / doi.org/10.1111/j.1949-8594.2010.00033.x

Brown, W. R., \& Wall, C. E. (1976). A Look at the Integration of Science and Mathematics in the Elementary School1976. School science and mathematics, 76(7), 551-562. https:/ / doi.org/10.1111/j.1949-8594.1976.tb09171.x

Clark-Carter, D. (1997). Doing quantitative psychological research: From design to report. East Sussex, UK: Psychology Press.

Cohen, J. (1988). Statistical power analysis for the behavioral sciences (2nd ed.). Hillsdale, NJ: Lawrence Earlbaum Associates.

Colucci-Gray, L., Camino, E., Barbiero, G., \& Gray, D. (2006). From scientific literacy to sustainability literacy: An ecological framework for education. Science Education, 90, 227-252. https:/ / doi.org/10.1002/ sce.20109

Cuadra, E., \& Moreno, J. M. (2005). Expanding opportunities and building competencies for young people: A new agenda for secondary education. Washington, DC: The World Bank.

Fountain, R. M. (1998). Sociologics: An analytical tool for examining socioscientific discourse. Research in Science Education, 28, 110-132. https:/ / doi.org/10.1007/BF02461646

Frykholm, J. \& Glasson, G. (2005). Connecting science and mathematics instruction: Pedagogical context knowledge for teachers. School Science and Mathematics, 105, 127-141. https://doi.org/10.1111/j.19498594.2005.tb18047.x

Furner, J. M., \& Kumar, D. D. (2007). The Mathematics and science integration argument: A stand for Teacher Education. Eurasia Journal of Mathematics, Science $\mathcal{E}$ Technology Education, 3, 185-189. https://doi.org/10.12973/ejmste/75397

Gainsburg, J. (2008). Real-world connections in secondary mathematics teaching. Journal of Mathematics Teacher Education, 11, 199-219. https:/ / doi.org/10.1007/s10857-007-9070-8

Gayford, C. (2002). Controversial environmental issues: a case study for the professional development of science teachers. International Journal of Science $\quad$ Education, 24, 1191-1200. https:/ / doi.org/10.1080/09500690210134866

Herman, B. C. (2015). The Influence of global warming science views and sociocultural factors on willingness to mitigate global warming, Science Education, 1, 1-38.

Herman, B. C. (2018). Students' environmental NOS views, compassion, intent, and action: Impact of place-based socioscientific issues instruction. Journal of Research in Science Teaching, 55, 600-638.

Herman, B. C., \& Clough, M. P. (2017). The role of History and Nature of Science in Climate Change Teaching and Learning. In Shepardson, D., Roychoudhury, A., \& Hirsch, A. (Eds.) Teaching and Learning about Climate Change: A Framework for Educators (pp. 31-44). New York, NY: Routledge.

Herman, B. C., Sadler, T. D., Zeidler, D. L., \& Newton, M. H. (2018). A socioscientific issues approach to environmental education. In Reis, G., \& Scott, J. (Eds.) International Perspectives on the Theory and Practice of Environmental Education: A Reader (pp. 145-161). New York, NY: Springer.

Hodson, D. (2009). Teaching and learning about science: Language, theories, methods, history, traditions and values. Boston, MA: Sense Publishers.

Jonsson, A., \& Svingby, G. (2007). The use of scoring rubrics: Reliability, validity and educational consequences. Educational Research Review, 2(2), 130-144. https:/ / doi.org/10.1016/j.edurev.2007.05.002

Kahn, S., \& Zeidler, D. L. (2016). Using our heads and HARTSS*: Developing perspective-taking skills for socioscientific reasoning ( ${ }^{*}$ Humanities, ARTs, and Social Sciences). Journal of Science Teacher Education, 27, 261-281. https:/ / doi.org/10.1007/s10972-016-9458-3

Karahan, E., \& Roehrig, G. (2017). Secondary school students' understanding of science and their socioscientific reasoning. Research in Science Education, 47, 755-782. https:/ / doi.org/10.1007/s11165-016-9527-9 
Kinslow, A. T. (April, 2018). The development and implementation of a heuristic for teaching reflective scientific skepticism within a socio-scientific issue instructional framework. Unpublished Doctoral Dissertation.

Kinslow, A. T., Sadler, T. D., \& Nguyen, H. T. (2018). Socio-scientific reasoning and environmental literacy in a field-based ecology class. Environmental Education Research, 1-23.

Kolstø, S. D. (2001). 'To trust or not to trust,...' - pupils' ways of judging information encountered in a socioscientific issue. International Journal of Science Education, 23, 877-901. https://doi.org/10.1080/09500690010016102

Kuhn, D. (1993). Science as argument: Implications for teaching and learning scientific thinking. Science Education, 77, 319-337. https:// doi.org/10.1002/sce.3730770306

Lee, H., Kyunghee, C., Kim, S., Jungsook, Y., Krajcik, J. S., Herman, B. C., \& Zeidler, D. L. (2013). Socioscientific issues as a vehicle for promoting character and values as global citizens. International Journal of Science Education, 35, 2079-2113.

Morin, O., Simonneaux, L., Simonneaux, J., \& Tytler, R. (2013). Digital technology to support students' socioscientific reasoning about environmental issues. Journal of Biological Education,47(3), 157-165. https://doi.org/10.1080/00219266.2013.821748

North American Association for Environmental Education (NAAEE). 2011. Developing a framework for assessing environmental literacy. North American Association for Environmental Education, Washington, D.C., USA.

Osborne, J. (2007). Science education for the twenty first century. Eurasia Journal of Mathematics, Science $\mathcal{E}$ Technology Education, 3, 173-184. https:/ / doi.org/10.12973/ejmste/75396

Owens, D. C., Sadler, T. D., \& Friedrichsen, P. (2019). Teaching Practices for Enactment of Socio-scientific Issues Instruction: an Instrumental Case Study of an Experienced Biology Teacher. Research in Science Education, 124.

Owens, D. C., Sadler, T. D., \& Zeidler, D. L. (2017). Controversial issues in the science classroom. Phi Delta Kappan, 99, 45-49.

Perdices, M. (2017). Null hypothesis significance testing, p-values, effects sizes and confidence intervals. Brain Impairment, 19, 70-80. https:/ / doi.org/10.1017/BrImp.2017.28

Romine, W. L., Sadler, T. D., \& Kinslow, A. T. (2017). Assessment of scientific literacy: Development and validation of the Quantitative Assessment of Socio-Scientific Reasoning (QuASSR). Journal of Research in Science Teaching, 54, 274-295.

Sadler, T. D. (2004). Informal reasoning regarding socioscientific issues: A critical review of research. Journal of Research in Science Teaching, 41, 513-536.

Sadler, T. D., \& Donnelly, L. A. (2006). Socioscientific argumentation: The effects of content knowledge and morality. International Journal of Science Education, 28, 1463-1488.

Sadler, T. D., \& Fowler, S. R. (2006). A threshold model of content knowledge transfer for socioscientific argumentation. Science Education, 90, 986-1004.

Sadler, T. D., Barab, S. A., \& Scott, B. (2007). What do students gain by engaging in socioscientific inquiry?. Research in Science Education, 37, 371-391.

Sadler, T. D., Klosterman, M. L., \& Topcu, M. S. (2011). Learning science content and socio-scientific reasoning through classroom explorations of global climate change. In T. D. Sadler (Ed.), Socio-scientific issues in the classroom. Teaching, learning and research (pp. 45-77). Dordrecht, Netherlands: Springer.

Sakschewski, M., Eggert, S., Schneider, S., \& Bögeholz, S. (2014). Students' Socioscientific Reasoning and Decisionmaking on Energy-related Issues-Development of a measurement instrument. International Journal of Science Education, 36(14), 2291-2313. https:/ / doi.org/10.1080/09500693.2014.920550

Schleigh, S. P., Bosse, M., \& Lee, T. (2011). Redefining curriculum integration and professional development: Inservice teachers as agents of change. Current Issues in Education, 14(3).

Shulman, L. S. (1986). Those who understand: Knowledge growth in teaching. Educational Researcher, 15, 4-14. https:/ / doi.org/10.3102/0013189X015002004

Simonneaux, L., \& Simonneaux, J. (2009). Students' socio-scientific reasoning on controversies from the viewpoint of education for sustainable development. Cultural Studies of Science Education, 4, 657-687. https:/ / doi.org/10.1007/s11422-008-9141-x

Soucy McCrone, S. M., Dossey, J. A., Turner, R., \& Lindquist, M. M. (2008). Learning about Student's Mathematical Literacy from PISA 2003. Mathematics Teacher, 102, 34-39.

Sullivan, G. M., \& Feinn, R. (2012). Using effect size-or why the $p$ value is not enough. Journal of Graduate Medical Education, 4, 279-282. https:/ / doi.org/10.4300/JGME-D-12-00156.1 
Tytler, R. (2001). Dimensions of evidence, the public understanding of science and science education. International Journal of Science Education, 23, 815-832. https:/ / doi.org/10.1080/09500690010016058

United Nations Educational, Scientific, and Cultural Organization and United Nations Environment Programme (UNESCO-UNEP). 1976. The Belgrade Charter. Connect: UNESCO-UNEP Environmental Education Newsletter $1,1-2$.

Wals, A. E., Brody, M., Dillon, J., \& Stevenson, R. B. (2014). Convergence between science and environmental education. Science, 344(6184), 583-584. https:/ / doi.org/10.1126/ science.1250515

Yager, R. E. (1993). Science-technology-society as reform. School Science and Mathematics, 93, 145-151. https:/ / doi.org/10.1111/j.1949-8594.1993.tb12213.x

Zeidler, D. L. (2016). STEM education: A deficit framework for the twenty first century? A sociocultural socioscientific response. Cultural Studies of Science Education, 11, 11-26. https:/ / doi.org/10.1007/s11422-0149578-z

Zohar, A., \& Nemet, F. (2002). Fostering students' knowledge and argumentation skills through dilemmas in human genetics. Journal of Research in Science Teaching, 39, 35-62. https:/ / doi.org/10.1002/ tea.10008

Zollman, A. (2012). Learning for STEM literacy: STEM literacy for learning. School Science and Mathematics, 112, 1219. https:/ / doi.org/10.1111/j.1949-8594.2012.00101.x 


\section{APPENDIX A: SSR PROMPT}

\section{Raccoon River Nitrates}

In Iowa, the counties of Buena Vista, Sac, and Calhoun are a region known as "Big Corn." Thanks to fertile soil, the heavy use of fertilizers, and modern farming techniques to facilitate the timely planting of crops in wet springtime conditions, the Big Corn region pumps out corn for feed and ethanol. This agricultural industry benefits the economy for the region and state, including the individuals residing in the surrounding rural areas (Who will pay, 2016).

Downstream from Big Corn is Des Moines, the largest city in Iowa. Des Moines' water supply is drawn from the Raccoon River - the same river that drains the watershed that includes the fields of Big Corn (Figure 1). Scientists at the Des Moines Water Works, the regional utility responsible for making the water safe to drink, indicated that water sampled from a variety of sites around Big Corn that drain into the Raccoon River showed nitrate levels four times higher than the federal limits for safe drinking water $(10 \mathrm{mg} / \mathrm{L}$; Neeley, 2017) - an unfortunate reality of fertilizers from the fields draining into the river. (Sands et al., 2012).

Nitrate is a dangerous compound in drinking water, as it stops oxygen from entering the human bloodstream. The cost for the city of Des Moines to filter nitrates from the water for their .5 million customers is about $\$ 7,000$ a day. The city argues that the polluted water resulting from fertilizer runoff should be regulated by the federal government as part of the Clean Water Act. City leaders have filed a lawsuit against the Farmers' Drainage Cooperative that governs drainage of the fields in Big Corn. This would require farmers to pay for the costly removal of nitrates from the water of the Raccoon River. A judgement for Des Moines would negatively affect farmers by making them responsible for runoff. For over 100 years the farmers have not been held responsible for polluting Iowa's waterways with agricultural runoff. The lawsuit has already cost citizens of Des Moines $\$ 1,000,000$.

A third party, the Iowa Partnership for Clean Water, indicates that its purpose is "to inform all stakeholders both rural and urban - about the consequences of frivolous legal action against farmers and the agriculture industry" (Iowa Partnership, 2016). This group argues that clean water is a priority, but they promote the voluntary use of technologies to do so, rather than legal actions. Concerning the Raccoon River situation, the Iowa Partnership for Clean Water suggests that the Farmers' Drainage Cooperative of Big Corn should use better farming practices to reduce fertilizer runoff and that Des Moines Water Works should upgrade the technology used in its treatment facilities. 


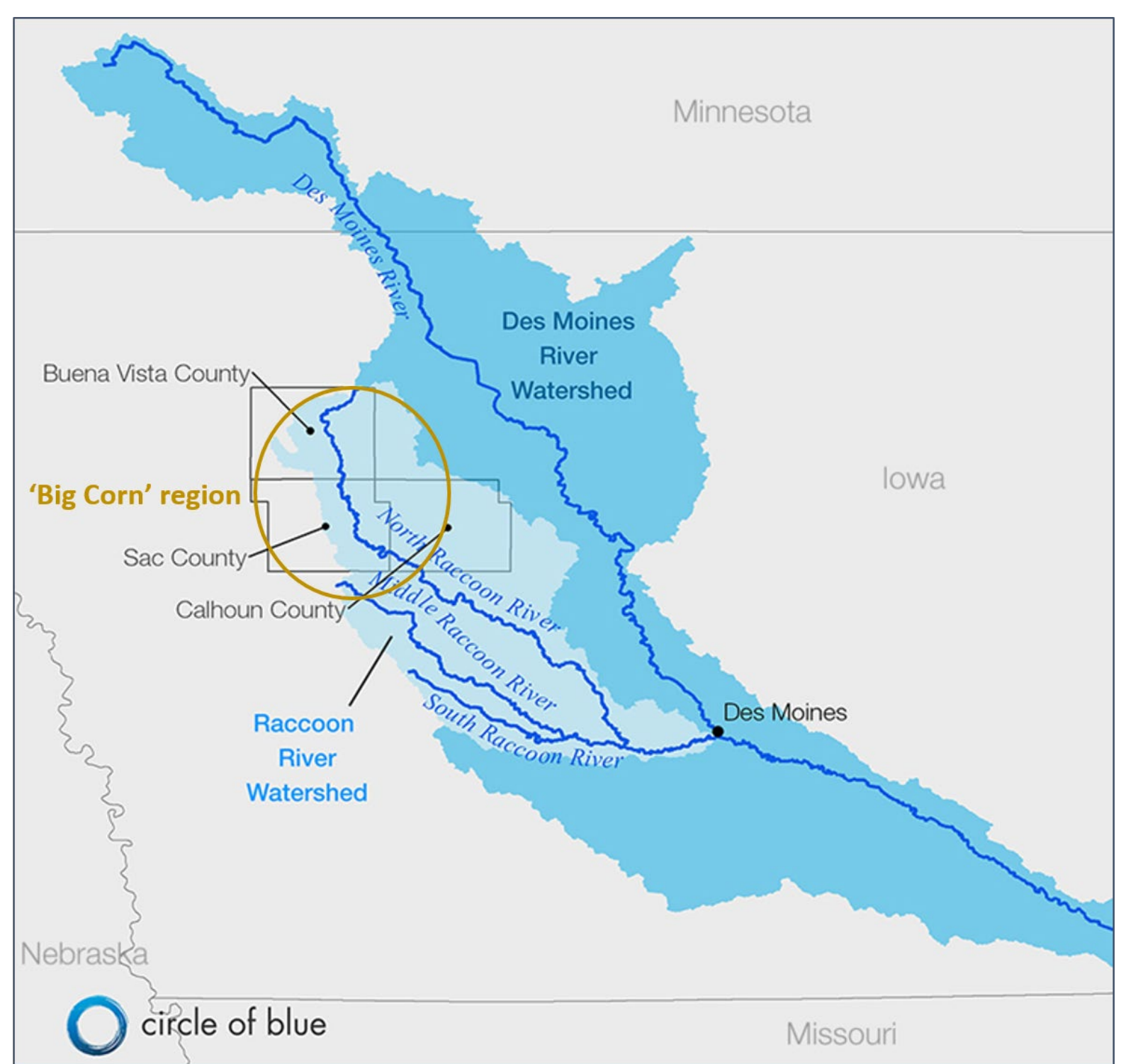

Figure 1. Highlighted in light blue is the Raccoon River watershed, including Buena Vista, Calhoun, and Sac County cornfields, which deliver nitrate-rich runoff from nearby farms to the city of Des Moines downstream (Photo: adopted from Walton, 2015)

All parties involved acknowledge that a water crisis is near, yet how it will be solved, and who will pay for that solution, is currently a hot debate topic.

1. Imagine that you are in charge of resolving this issue. Would this be a difficult issue to resolve?
A) YES

B) $\mathrm{NO}$

If YES, then: What aspects of this issue make it difficult to resolve? (Please provide as much detail as possible.) If NO, then: Why do you think this issue is easily resolved? (Please provide as much detail as possible.)

2. If you were responsible for deciding how to resolve the Raccoon River nitrates issue, would you need additional information regarding the situation before making your decision?

A) Yes, I would need to have additional information to make a decision. (Please provide as much detail as possible.)

B) No, I have sufficient information to make a decision. (Please provide as much detail as possible.) 
If YES, then: What kinds of additional information would be necessary for you to make a decision regarding the Raccoon River nitrates issue? (Please support your response with details and/or examples)

If NO, then: What information would be most important for your decision-making? (Please support your response with details and/or examples)

3. Iowa officials suggest that the best approach to reducing nitrates in the Racoon River is by requiring the Farmers' Drainage Cooperative of Big Corn to use precision agriculture practices to reduce fertilizer runoff and requiring the Des Moines Water Works to upgrade the technology used in its treatment facilities.

3a. How do you think Farmers' Drainage Cooperative of Big Corn would respond to this suggestion? (Please support your response with details and/or examples)

3 b. How do you think the residents of Des Moines would respond to this suggestion? (Please support your response with details and/or examples)

4. The local leaders working on this issue ask you to write a report that summarizes the Racoon River issue and predict consequences of different solutions. The following sources of information are available to you:

Interviews with Big Corn farmers \& residents of Des Moines

Social Media, Blog, and Wikipedia posts about the issue

Research studies published in reputable science journals

Are these equally good sources of information for the preparation of your report?

A) YES

B) $\mathrm{NO}$

If YES, then: Explain why you think these sources are equally good. Be as specific as possible. (Please support your response with details and/or examples)

If NO, then: Explain why you think there are differences in the quality of these three sources of information. Be as specific as possible. (Please support your response with details and/or examples)

5. A town hall meeting is organized to discuss the Raccoon River nitrates issue. The following presentations are given:

A report from scientists hired by the Farmer's cooperative

A report from scientists hired by the Des Moines Water Works

Would you expect these reports to be similar or different?

If SIMILAR, then: Why would the reports be similar? (Please support your response with details and/or examples)

If DIFFERENT, then: Why would the reports be different? (Please support your response with details and/or examples)

6. Do you think that scientists can help to resolve the Raccoon River issue?

IF Yes, What could scientists do to help resolve the issue? (Please support your response with details and/or examples)

IF NO, Why would scientists NOT be helpful for resolving this issue? (Please support your response with details and/or examples)

7. Some people think that a full understanding of the science related to the Raccoon River Nitrates problem will provide the best solution. Others suggest that a solution should be informed by the science as well as other, nonscience considerations. What do you think?

A. The solution to the Raccoon River Nitrates problem should be determined by the science.

B. The solution to the Raccoon River Nitrates problem should be determined by the science AND other, nonscience considerations.

If A, Why should the solution to the Raccoon River Nitrates problem be determined by scientific information? (Please support your response with details and/or examples) 
If $\mathrm{B}$, What non-science information should be considered in order to determine a good solution for the Raccoon River Nitrates problem? (Please support your response with details and/or examples)

\section{Literature cited}

Iowa partnership for clean water responds to Des Moines Water Works' Decision to direct an additional $\$ 650,0000$ to lawsuit. (2016, May 25). Retrieved from http://iowapartnershipforcleanwater.org/2016/05/iowapartnership-for-clean-water-responds-to-des-moines-water-works-decision-to-direct-an-additional650000-to-lawsuit/

Neeley, T. (2017, January 27). Damages not allowed in Iowa runoff case: Iowa high court rules against Des Moines Water Works. Retrieved from https://www.dtnpf.com/agriculture/web/ag/news/article/2017/01/27/ iowa-high-court-rules-des-moines

Sands, G. R., Hay, C., Kandel, H., \& Scherer, T. (2012). Frequently asked questions about subsurface (tile) drainage in the red river valley [PDF document]. Retrieved from the University of Minnesota Extension website: https://www.extension.umn.edu/agriculture/water/publications/pdfs/faqs_of_tile_drainageprint_6131 3.pdf

Walton, B. (2015, March 9). Des Moines Water Utility to File Nitrate Pollution Lawsuit. Retrieved from http:/ / www.circleofblue.org/2015/world/ des-moines-water-utility-file-nitrate-pollution-lawsuit/

Who will pay for water pollution cleanup divides urban and rural Iowa. (2016, October 25). Retrieved from http://www.pbs.org/newshour/bb/will-pay-water-pollution-cleanup-divides-urban-rural-iowa/ 


\section{APPENDIX B: SSR RUBRIC}

\begin{tabular}{|c|c|c|c|c|c|c|c|}
\hline & Complexity & Inquiry & $\begin{array}{l}\text { Perspective- } \\
\text { Taking } \\
\end{array}$ & \multicolumn{2}{|l|}{ Skepticism } & \multicolumn{2}{|c|}{$\begin{array}{l}\text { Affordance of Science and Non- } \\
\text { Science Considerations }\end{array}$} \\
\hline Lvl & Q1 & Q2 & Q3 & $\begin{array}{l}\text { Q4 - SSI } \\
\text { Information } \\
\text { Sources } \\
\end{array}$ & $\begin{array}{l}\text { Q5 - } \\
\text { Scientists' } \\
\text { Reporting } \\
\end{array}$ & Q6 - Science & Q7 - Non-Science \\
\hline 0 & $\begin{array}{l}\text { Suggests that } \\
\text { the issue is } \\
\text { not complex } \\
\text { or provides } \\
\text { an illogical } \\
\text { response. }\end{array}$ & $\begin{array}{l}\text { Suggests that } \\
\text { no further } \\
\text { inquiry is } \\
\text { required or } \\
\text { provides an } \\
\text { illogical } \\
\text { response. }\end{array}$ & $\begin{array}{l}\text { Presents } \\
\text { perspectives that } \\
\text { are NOT consistent } \\
\text { with stakeholder } \\
\text { views }\end{array}$ & $\begin{array}{l}\text { Suggests that } \\
\text { the sources } \\
\text { are equally } \\
\text { good. }\end{array}$ & $\begin{array}{l}\text { Suggests that } \\
\text { the reports } \\
\text { would be } \\
\text { similar or } \\
\text { provides an } \\
\text { illogical } \\
\text { response. }\end{array}$ & $\begin{array}{l}\text { Suggests that } \\
\text { science would } \\
\text { not be helpful } \\
\text { or provides an } \\
\text { illogical } \\
\text { response. }\end{array}$ & $\begin{array}{l}\text { Suggests that } \\
\text { science alone can } \\
\text { solve the issue or } \\
\text { provides an } \\
\text { illogical response. }\end{array}$ \\
\hline 1 & $\begin{array}{l}\text { Identifies at } \\
\text { least one } \\
\text { source of } \\
\text { complexity. }\end{array}$ & $\begin{array}{l}\text { Identifies an } \\
\text { area of further } \\
\text { inquiry. }\end{array}$ & $\begin{array}{l}\text { Presents a } \\
\text { perspective } \\
\text { consistent with a } \\
\text { stakeholder view. }\end{array}$ & $\begin{array}{l}\text { Identifies one } \\
\text { reason for } \\
\text { differences in } \\
\text { source } \\
\text { quality. }\end{array}$ & $\begin{array}{l}\text { Identifies one } \\
\text { way in which } \\
\text { the reports } \\
\text { would be } \\
\text { different. }\end{array}$ & $\begin{array}{l}\text { Identifies one } \\
\text { way in which } \\
\text { science would } \\
\text { be helpful for } \\
\text { issue resolution. }\end{array}$ & $\begin{array}{l}\text { Identifies one non- } \\
\text { science } \\
\text { consideration. }\end{array}$ \\
\hline 2 & $\begin{array}{l}\text { Identifies at } \\
\text { least one } \\
\text { source of } \\
\text { complexity } \\
\text { and provides } \\
\text { a contextual } \\
\text { explanation } \\
\text { or } \\
\text { justification } \\
\text { of a source }\end{array}$ & $\begin{array}{l}\text { Identifies at } \\
\text { least one area } \\
\text { of further } \\
\text { inquiry and } \\
\text { provides a } \\
\text { contextual } \\
\text { explanation, } \\
\text { justification, or } \\
\text { description of } \\
\text { an area of } \\
\text { inquiry }\end{array}$ & $\begin{array}{l}\text { Presents a } \\
\text { perspective } \\
\text { consistent with a } \\
\text { stakeholder view } \\
\text { and provides a } \\
\text { contextual } \\
\text { explanation, } \\
\text { justification, or } \\
\text { elaboration of the } \\
\text { perspective. }\end{array}$ & $\begin{array}{l}\text { Identifies one } \\
\text { reason for } \\
\text { differences in } \\
\text { source } \\
\text { quality and } \\
\text { provides an } \\
\text { explanation } \\
\text { or } \\
\text { justification } \\
\text { for the } \\
\text { difference. }\end{array}$ & $\begin{array}{l}\text { Identifies one } \\
\text { way in which } \\
\text { the reports } \\
\text { would be } \\
\text { different and } \\
\text { provides an } \\
\text { explanation or } \\
\text { justification } \\
\text { for the } \\
\text { difference. }\end{array}$ & $\begin{array}{l}\text { Identifies one } \\
\text { way in which } \\
\text { science would } \\
\text { be helpful and } \\
\text { provides an } \\
\text { explanation or } \\
\text { justification. }\end{array}$ & $\begin{array}{l}\text { Identifies one non- } \\
\text { science } \\
\text { consideration and } \\
\text { provides an } \\
\text { explanation or } \\
\text { description. }\end{array}$ \\
\hline 3 & $\begin{array}{l}\text { Identifies at } \\
\text { least two } \\
\text { sources of } \\
\text { complexity } \\
\text { and provides } \\
\text { a contextual } \\
\text { explanation } \\
\text { or } \\
\text { justification } \\
\text { for one of } \\
\text { those sources }\end{array}$ & $\begin{array}{l}\text { Identifies at } \\
\text { least two areas } \\
\text { of further } \\
\text { inquiry and } \\
\text { provides } \\
\text { contextual } \\
\text { explanation, } \\
\text { justification, or } \\
\text { description for } \\
\text { one of those } \\
\text { areas }\end{array}$ & $\begin{array}{l}\text { Presents } \\
\text { perspectives } \\
\text { consistent with both } \\
\text { stakeholder views } \\
\text { and provides a } \\
\text { contextual } \\
\text { explanation, } \\
\text { justification, or } \\
\text { elaboration of one } \\
\text { of those } \\
\text { perspectives. }\end{array}$ & $\begin{array}{l}\text { Identifies } \\
\text { two reasons } \\
\text { for } \\
\text { differences in } \\
\text { source } \\
\text { quality and } \\
\text { provides an } \\
\text { explanation } \\
\text { or } \\
\text { justification } \\
\text { for one } \\
\text { difference. }\end{array}$ & $\begin{array}{l}\text { Identifies two } \\
\text { ways in which } \\
\text { the reports } \\
\text { would be } \\
\text { different and } \\
\text { provides an } \\
\text { explanation or } \\
\text { justification } \\
\text { for one } \\
\text { difference. }\end{array}$ & $\begin{array}{l}\text { Identifies two } \\
\text { ways in which } \\
\text { science would } \\
\text { be helpful and } \\
\text { provides an } \\
\text { explanation or } \\
\text { justification for } \\
\text { one. }\end{array}$ & $\begin{array}{l}\text { Identifies at least } \\
\text { two non-science } \\
\text { considerations and } \\
\text { provides an } \\
\text { explanation or } \\
\text { description for one } \\
\text { consideration. }\end{array}$ \\
\hline 4 & $\begin{array}{l}\text { Identifies two } \\
\text { or more } \\
\text { sources of } \\
\text { complexity } \\
\text { and provides } \\
\text { contextual } \\
\text { explanations } \\
\text { or } \\
\text { justifications } \\
\text { for at least } \\
\text { two of those } \\
\text { sources. }\end{array}$ & $\begin{array}{l}\text { Identifies Two } \\
\text { or more areas } \\
\text { of inquiry and } \\
\text { provides } \\
\text { contextual } \\
\text { explanation/ju } \\
\text { stification/des } \\
\text { cription for at } \\
\text { least two. }\end{array}$ & $\begin{array}{l}\text { Presents } \\
\text { perspectives } \\
\text { consistent with both } \\
\text { stakeholder views } \\
\text { and provides a } \\
\text { contextual } \\
\text { explanation, } \\
\text { justification, or } \\
\text { elaboration of both } \\
\text { perspectives. }\end{array}$ & $\begin{array}{l}\text { Identifies } \\
\text { two reasons } \\
\text { for } \\
\text { differences in } \\
\text { source } \\
\text { quality and } \\
\text { provides an } \\
\text { explanation } \\
\text { or } \\
\text { justification } \\
\text { for both } \\
\text { differences. }\end{array}$ & $\begin{array}{l}\text { Identifies two } \\
\text { ways in which } \\
\text { the reports } \\
\text { would be } \\
\text { different and } \\
\text { provides an } \\
\text { explanation or } \\
\text { justification } \\
\text { for both } \\
\text { differences. }\end{array}$ & $\begin{array}{l}\text { Identifies two } \\
\text { ways in which } \\
\text { science would } \\
\text { be helpful and } \\
\text { provides an } \\
\text { explanation or } \\
\text { justification for } \\
\text { both. }\end{array}$ & $\begin{array}{l}\text { Identifies at least } \\
\text { two non-science } \\
\text { considerations and } \\
\text { provides an } \\
\text { explanation or } \\
\text { description for two } \\
\text { considerations. }\end{array}$ \\
\hline
\end{tabular}




\section{APPENDIX C: LEVELS OF SSR SOPHISTICATION WITH EXEMPLAR QUOTES}

Table 1. Rubric and exemplars for the Complexity dimension of SSR

\begin{tabular}{|c|c|c|c|c|c|}
\hline & \multicolumn{5}{|c|}{ Levels } \\
\hline & 0 & 1 & 2 & 3 & 4 \\
\hline Complexity & $\begin{array}{l}\text { Suggests that the } \\
\text { issue is not complex } \\
\text { or provides an } \\
\text { illogical response. }\end{array}$ & $\begin{array}{l}\text { Identifies at least } \\
\text { one source of } \\
\text { complexity. }\end{array}$ & $\begin{array}{l}\text { Identifies at least one } \\
\text { source of } \\
\text { complexity and } \\
\text { provides a contextual } \\
\text { explanation or } \\
\text { justification for one } \\
\text { source. }\end{array}$ & $\begin{array}{l}\text { Identifies at least two sources } \\
\text { of complexity and provides a } \\
\text { contextual explanation or } \\
\text { justification for one of those } \\
\text { sources. }\end{array}$ & $\begin{array}{l}\text { Identifies two or more } \\
\text { sources of complexity } \\
\text { and provides contextual } \\
\text { explanations or } \\
\text { justifications for at least } \\
\text { two of those sources. }\end{array}$ \\
\hline $\begin{array}{l}\text { Fixed choice response: } \\
\text { Would this be a difficult } \\
\text { issue to resolve? }\end{array}$ & & Yes & Yes & Yes & Yes \\
\hline Exemplar Quote & No exemplar & $\begin{array}{l}\text { [There are] 3-4 } \\
\text { different groups } \\
\text { with completely } \\
\text { different views of } \\
\text { the topic. }\end{array}$ & $\begin{array}{l}\text { You are dealing with } \\
\text { the livelihoods of all } \\
\text { the stakeholders } \\
\text { involved. The decision } \\
\text { that is made will } \\
\text { affect everyone } \\
\text { greatly. }\end{array}$ & $\begin{array}{l}\text { Additional information I would } \\
\text { need would be from the } \\
\text { farmer. What are you already } \\
\text { doing to make sure you are } \\
\text { following healthy } \\
\text { environmental issues? Are you } \\
\text { doing periodic tests on the } \\
\text { amount of nitrates in your area } \\
\text { and the watershed? From the } \\
\text { city, I would want to know if } \\
\text { this increase in nitrates is year } \\
\text { round or just during certain } \\
\text { months. I would also want to } \\
\text { know how often they improve } \\
\text { their equipment - do they wait } \\
\text { a long time and then replace } \\
\text { very outdated equipment? }\end{array}$ & $\begin{array}{l}\text { The people affected are } \\
\text { in the state's capital, so } \\
\text { there are overarching } \\
\text { political ramifications. } \\
\text { The solution is an } \\
\text { expensive one, which } \\
\text { would burden the } \\
\text { individual farmers, the } \\
\text { very people responsible } \\
\text { for the economic boon. } \\
\text { The effect has resulted } \\
\text { from years of long term } \\
\text { fertilizer use... [but] } \\
\text { the health of Des } \\
\text { Moines depends on a } \\
\text { swift resolution. }\end{array}$ \\
\hline
\end{tabular}

Table 2. Rubric and exemplars for the Inquiry dimension of SSR

\begin{tabular}{|c|c|c|c|c|c|}
\hline & \multicolumn{5}{|c|}{ Levels } \\
\hline & 0 & 1 & 2 & 3 & 4 \\
\hline Inquiry & $\begin{array}{l}\text { Suggests that } \\
\text { no further } \\
\text { inquiry is } \\
\text { required or } \\
\text { provides an } \\
\text { illogical } \\
\text { response. }\end{array}$ & $\begin{array}{l}\text { Identifies an } \\
\text { area of } \\
\text { further } \\
\text { inquiry. }\end{array}$ & $\begin{array}{l}\text { Identifies at least } \\
\text { one area of } \\
\text { further inquiry } \\
\text { and provides a } \\
\text { contextual } \\
\text { explanation, } \\
\text { justification, or } \\
\text { description of an } \\
\text { area of inquiry }\end{array}$ & $\begin{array}{l}\text { Identifies at least two } \\
\text { areas of further } \\
\text { inquiry and provides } \\
\text { contextual explanation, } \\
\text { justification, or } \\
\text { description for one of } \\
\text { those areas }\end{array}$ & $\begin{array}{l}\text { Identifies at least two areas of further inquiry and } \\
\text { provides contextual explanation, justification, or } \\
\text { description for at least two }\end{array}$ \\
\hline $\begin{array}{l}\text { Fixed choice } \\
\text { response: } \\
\text { Is additional } \\
\text { information } \\
\text { needed before } \\
\text { making a } \\
\text { decision on } \\
\text { the issue? }\end{array}$ & & Yes & Yes & Yes & Yes \\
\hline $\begin{array}{l}\text { Exemplar } \\
\text { Quote }\end{array}$ & No exemplar & $\begin{array}{l}\text { More } \\
\text { background } \\
\text { information } \\
\text { for what this } \\
\text { situation is } \\
\text { about. More } \\
\text { information } \\
\text { on what } \\
\text { types of } \\
\text { things can } \\
\text { be done for } \\
\text { making a } \\
\text { plan to } \\
\text { clean up the } \\
\text { pollution. }\end{array}$ & $\begin{array}{l}\text { What are some } \\
\text { technologies } \\
\text { currently In place } \\
\text { that could help } \\
\text { solve the problem, } \\
\text { [such as] cheaper } \\
\text { ways to clean the } \\
\text { water of nitrates or } \\
\text { different fertilizer } \\
\text { with lower nitrate } \\
\text { levels. }\end{array}$ & $\begin{array}{l}\text { I would like to know } \\
\text { how many people are in } \\
\text { the three counties that } \\
\text { makeup The Big Corn } \\
\text { region. Such } \\
\text { information would let } \\
\text { me know whether or } \\
\text { not the people of the } \\
\text { counties could } \\
\text { realistically pay for the } \\
\text { capital's water problem. } \\
\text { I would like to know } \\
\text { what technology is } \\
\text { available to upgrade } \\
\text { water treatment } \\
\text { facilities. }\end{array}$ & $\begin{array}{l}\text { Quantitative information would need to be provided } \\
\text { about the nitrate levels at the location where the } \\
\text { drinking water is removed from the river; the } \\
\text { information provided only states that samples were } \\
\text { taken around Big Corn and these sites drain into the } \\
\text { Raccoon River. High levels at these sites do not } \\
\text { necessarily mean high levels at the out take point for } \\
\text { drinking water collection. Scientific data needs to be } \\
\text { provided to show that a change in farming practices } \\
\text { including improved drainage techniques and the use } \\
\text { of improved technology by the Des Moines Water } \\
\text { Works would actually be successful in removing the } \\
\text { dangerous nitrates. Treatment facility upgrades might } \\
\text { improve the water quality in the area but how much } \\
\text { of that problem would have actually been caused by } \\
\text { farming practices? }\end{array}$ \\
\hline
\end{tabular}


EURASIA J Math Sci and Tech Ed

Table 3. Rubric and exemplars for the Perspective-Taking dimension of SSR

\begin{tabular}{|c|c|c|c|c|c|}
\hline & \multicolumn{5}{|c|}{ Levels } \\
\hline & 0 & 1 & 2 & 3 & 4 \\
\hline Perspective-Taking & $\begin{array}{l}\text { Presents perspectives } \\
\text { that are not consistent } \\
\text { with stakeholder views } \\
\text { OR } \\
\text { Judgment answer with } \\
\text { no detail (ie "they } \\
\text { would not like it") }\end{array}$ & $\begin{array}{l}\text { Presents a } \\
\text { perspective } \\
\text { consistent with a } \\
\text { stakeholder view. }\end{array}$ & $\begin{array}{l}\text { Presents a } \\
\text { perspective } \\
\text { consistent with a } \\
\text { stakeholder view and } \\
\text { provides a contextual } \\
\text { explanation, } \\
\text { justification, or } \\
\text { elaboration of the } \\
\text { perspective. }\end{array}$ & $\begin{array}{l}\text { Presents perspectives } \\
\text { consistent with both } \\
\text { stakeholder views and } \\
\text { provides a contextual } \\
\text { explanation, } \\
\text { justification, or } \\
\text { elaboration of one of } \\
\text { those perspectives. }\end{array}$ & $\begin{array}{l}\text { Presents perspectives } \\
\text { consistent with both } \\
\text { stakeholder views and } \\
\text { provides a contextual } \\
\text { explanation, } \\
\text { justification, or } \\
\text { elaboration of both } \\
\text { perspectives. }\end{array}$ \\
\hline
\end{tabular}

Open-ended response:

How do you think

Farmers' Drainage

Cooperative of Big

Corn would respond to

this suggestion?

How do you think the

residents of Des

Moines would respond

to this suggestion?

Big Corn:

I have absolutely no

idea.

Exemplar Quote

Concerned Citizens:

I have absolutely no

idea.

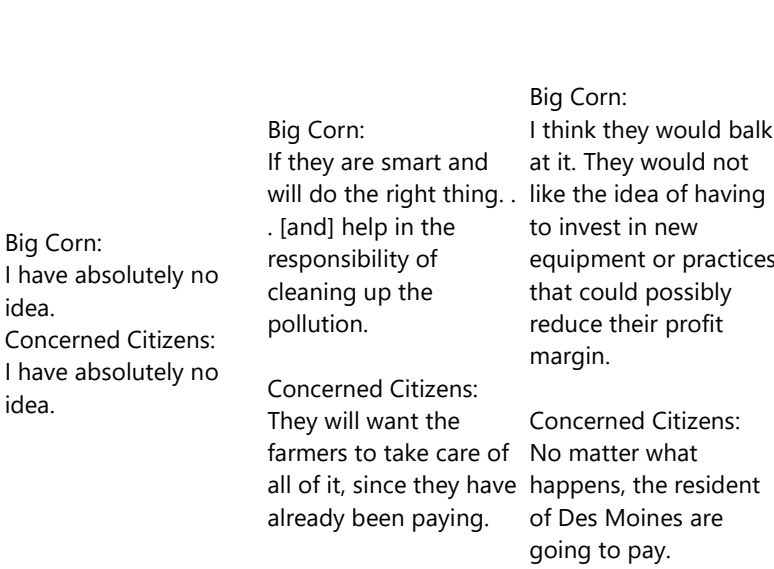

Big Corn:

Farmers' Drainage

Cooperative might

respond with the idea

that they are already

using the best farming practices.

Concerned Citizens:

The citizens might not

like this suggestion

because the Water

Works will need to

spend money to

upgrade their

technology, which

might increase the

water bills of the

citizens.
Big Corn:

... would probably to

look for support

financially in the

precision agriculture

practices to reduce

runoff since that would

come with additional

costs that the farmers

have not had in the

past 100 years. They

might also wonder why

they have incur these

costs if it is not their

current water supply

but a big city's issue.

Concerned Citizens:

... would probably also question why and how much they have to pay to fix a problem that someone else caused. They might want to instead push all of the costs onto someone else. 
Table 4. Rubric and exemplars for the Skepticism dimension of SSR (SSI Information Sources)

\begin{tabular}{|c|c|c|c|c|c|}
\hline & \multicolumn{5}{|c|}{ Levels } \\
\hline & 0 & 1 & 2 & 3 & 4 \\
\hline $\begin{array}{l}\text { Skepticism - } \\
\text { SSI Information } \\
\text { Sources }\end{array}$ & $\begin{array}{l}\text { Suggests that the } \\
\text { sources are equally good } \\
\text { OR fails to identify a } \\
\text { reason for differences in } \\
\text { source quality. }\end{array}$ & $\begin{array}{l}\text { Identifies one } \\
\text { reason for } \\
\text { differences } \\
\text { in source } \\
\text { quality. }\end{array}$ & $\begin{array}{l}\text { Identifies one reason } \\
\text { for differences in } \\
\text { source quality and } \\
\text { provides an explanation } \\
\text { or justification for the } \\
\text { difference. }\end{array}$ & $\begin{array}{l}\text { Identifies two } \\
\text { reasons for } \\
\text { differences in } \\
\text { source quality } \\
\text { and provides an } \\
\text { explanation or } \\
\text { justification for } \\
\text { one difference. }\end{array}$ & $\begin{array}{l}\text { Identifies two reasons for differences } \\
\text { in source quality and provides an } \\
\text { explanation or justification for both } \\
\text { differences. }\end{array}$ \\
\hline $\begin{array}{l}\text { Fixed choice } \\
\text { response: Are these } \\
\text { equally good sources } \\
\text { of information for the } \\
\text { preparation of your } \\
\text { report? }\end{array}$ & Yes & No & No & No & No \\
\hline Exemplar Quote & $\begin{array}{l}\text { Information from public } \\
\text { is important; it is an } \\
\text { emotional and public } \\
\text { issue. If nothing else, it } \\
\text { will help the people in } \\
\text { charge of this issue } \\
\text { realize what PR moves } \\
\text { need to be done for } \\
\text { explanation and } \\
\text { education to all } \\
\text { stakeholders. } \\
\text { Social media, etc. is } \\
\text { important for all reasons } \\
\text { above...too many people } \\
\text { believe that what they } \\
\text { read online is } \\
\text { true...therefore we must } \\
\text { know what's online so } \\
\text { that we can educate } \\
\text { research studies: should } \\
\text { be updated scientific } \\
\text { information }\end{array}$ & $\begin{array}{l}\text { The interviews } \\
\text { and social } \\
\text { media are } \\
\text { more opinion } \\
\text { and the } \\
\text { research are } \\
\text { based in facts. }\end{array}$ & $\begin{array}{l}\text { Depending on the } \\
\text { context of the sources } \\
\text { they may all be useful } \\
\text { however, in the same } \\
\text { regard depending on } \\
\text { the context they may } \\
\text { not be as useful. When } \\
\text { using these sources you } \\
\text { should be careful to } \\
\text { evaluate for bias. This } \\
\text { issue hits close to home } \\
\text { for many, both the } \\
\text { farmers and residents } \\
\text { who rely on the water } \\
\text { for drinking water, and } \\
\text { their opinion are } \\
\text { important but should } \\
\text { only be used as such. }\end{array}$ & $\begin{array}{l}\text { Science journals } \\
\text { are peer } \\
\text { reviewed and } \\
\text { based on } \\
\text { evidence. } \\
\text { Interviews with } \\
\text { people/organizat } \\
\text { ions, social } \\
\text { media, etc. are all } \\
\text { opinion based } \\
\text { (rather than fact- } \\
\text { based) and } \\
\text { reflect personal } \\
\text { biases, } \\
\text { misleading } \\
\text { information, and } \\
\text { sometimes even } \\
\text { conspiracy } \\
\text { theories. }\end{array}$ & $\begin{array}{l}\text { Sources may be biased toward one } \\
\text { stakeholder's interests. For example, a } \\
\text { farmer is likely to be opposed to } \\
\text { changing farming methods because of } \\
\text { the additional cost regardless of the } \\
\text { fact that nitrates in drinking water can } \\
\text { have serious implications for } \\
\text { consumers... Citizens are going to be } \\
\text { biased based on health concerns and } \\
\text { will believe that farmers should be } \\
\text { responsible for the costs since they are } \\
\text { the source of the pollution. Social } \\
\text { media, blogs, and Wikipedias may be } \\
\text { laced with inaccurate information or } \\
\text { misconceptions since they are not } \\
\text { likely written by experts. They may also } \\
\text { be biased by the writer's emotions and } \\
\text { interests. } \\
\text { Information in scientific journals would } \\
\text { be the most reliable since it is based } \\
\text { on factual data and is peer-reviewed } \\
\text { before publication. However, data can } \\
\text { sometimes be manipulated while still } \\
\text { be accurate at face-value. }\end{array}$ \\
\hline
\end{tabular}

Table 5. Rubric and exemplars for the Skepticism dimension of SSR (Scientists' Reporting)

\begin{tabular}{|c|c|c|c|c|c|}
\hline & \multicolumn{5}{|l|}{ Levels } \\
\hline & 0 & 1 & 2 & 3 & 4 \\
\hline $\begin{array}{l}\text { Skepticism - } \\
\text { Scientists' Reporting }\end{array}$ & $\begin{array}{l}\text { Suggests that the } \\
\text { scientists' reports } \\
\text { would be the same OR } \\
\text { provides an illogical } \\
\text { response. }\end{array}$ & $\begin{array}{l}\text { Identifies one way } \\
\text { in which the } \\
\text { reports would be } \\
\text { different. }\end{array}$ & $\begin{array}{l}\text { Identifies one_way in } \\
\text { which the reports would } \\
\text { be different (explicit or } \\
\text { implied) and provides an } \\
\text { explanation or justification } \\
\text { for the difference. }\end{array}$ & $\begin{array}{l}\text { Identifies two ways in } \\
\text { which the reports } \\
\text { would be different } \\
\text { and provides an } \\
\text { explanation or } \\
\text { justification for one } \\
\text { difference. }\end{array}$ & $\begin{array}{l}\text { Identifies two ways in } \\
\text { which the reports } \\
\text { would be different } \\
\text { and provides an } \\
\text { explanation or } \\
\text { justification for both } \\
\text { differences. }\end{array}$ \\
\hline $\begin{array}{l}\text { Fixed choice response } \\
\text { Would you expect } \\
\text { these reports to be } \\
\text { similar or different? }\end{array}$ & Similar & Different & Different & & \\
\hline Exemplar Quote & $\begin{array}{l}\text { They are both given } \\
\text { from a scientists, so the } \\
\text { information would be } \\
\text { similar. }\end{array}$ & $\begin{array}{l}\text { The reports would } \\
\text { be different to } \\
\text { show data that } \\
\text { would reflect } \\
\text { positively for the } \\
\text { party concerned. }\end{array}$ & $\begin{array}{l}\text { Each of the scientists will } \\
\text { show evidence to support } \\
\text { their side and against the } \\
\text { other side. They both could } \\
\text { easily use statistics or data } \\
\text { to show positive influence } \\
\text { for their opinion or to } \\
\text { demonstrate that their side } \\
\text { should win. }\end{array}$ & No exemplar & No exemplar \\
\hline
\end{tabular}


EURASIA J Math Sci and Tech Ed

Table 6. Rubric and exemplars for the Affordances of Science and Non-Science Considerations dimension of SSR (Science)

\begin{tabular}{|c|c|c|c|c|c|}
\hline & \multicolumn{5}{|c|}{ Levels } \\
\hline & 0 & 1 & 2 & 3 & 4 \\
\hline Affordances of Science & $\begin{array}{l}\text { Suggests that } \\
\text { science would not } \\
\text { be helpful OR } \\
\text { provides an } \\
\text { illogical response. }\end{array}$ & $\begin{array}{l}\text { Identifies one } \\
\text { way in which } \\
\text { science would } \\
\text { be helpful for } \\
\text { issue } \\
\text { resolution. }\end{array}$ & $\begin{array}{l}\text { Identifies one way } \\
\text { in which science } \\
\text { would be helpful } \\
\text { and provides an } \\
\text { explanation or } \\
\text { justification. }\end{array}$ & $\begin{array}{l}\text { Identifies two ways in which } \\
\text { science would be helpful and } \\
\text { provides an explanation or } \\
\text { justification for one. }\end{array}$ & $\begin{array}{l}\text { Identifies two ways in which } \\
\text { science would be helpful and } \\
\text { provides an explanation or } \\
\text { justification for both. }\end{array}$ \\
\hline $\begin{array}{l}\text { Fixed choice response: } \\
\text { Do you think scientists } \\
\text { can help resolve the } \\
\text { issue? }\end{array}$ & No & Yes & Yes & Yes & Yes \\
\hline Exemplar Quote & $\begin{array}{l}\text { The problem here } \\
\text { is not scientific. } \\
\text { Everybody agrees } \\
\text { nitrates are in the } \\
\text { river, and are } \\
\text { harmful. The } \\
\text { problem is } \\
\text { political - who is } \\
\text { going to take the } \\
\text { responsibility for } \\
\text { fixing it? This is } \\
\text { not part of what } \\
\text { scientists are } \\
\text { supposed to do. }\end{array}$ & $\begin{array}{l}\text { Scientists can } \\
\text { provide facts } \\
\text { about the } \\
\text { problem, } \\
\text { predictions for } \\
\text { the future if } \\
\text { certain actions } \\
\text { are taken (or } \\
\text { no action } \\
\text { taken at all) as } \\
\text { well as } \\
\text { possible } \\
\text { solutions. }\end{array}$ & $\begin{array}{l}\text { Scientists are } \\
\text { problem solvers } \\
\text { and can possibly } \\
\text { figure out a better } \\
\text { and more effective } \\
\text { way to deal with } \\
\text { the nitrates in the } \\
\text { water. Maybe there } \\
\text { is something that } \\
\text { can be put into the } \\
\text { water to break } \\
\text { down the nitrates } \\
\text { in a more effective } \\
\text { way. }\end{array}$ & $\begin{array}{l}\text { Scientists could help resolve } \\
\text { the issue just by gathering } \\
\text { data, showing the science } \\
\text { behind nitrate infiltration, } \\
\text { showing the amounts of } \\
\text { nitrates at many locations. } \\
\text { With the raw data, both sides } \\
\text { would be able to develop their } \\
\text { own conclusions about what } \\
\text { needs to happen. Scientists } \\
\text { could also help with showing } \\
\text { solutions that have helped } \\
\text { other areas or that would work } \\
\text { because of the science } \\
\text { involved in what is done. }\end{array}$ & $\begin{array}{l}\text { They could explain the } \\
\text { complexities of the issue to all } \\
\text { stakeholders, describing the } \\
\text { importance of nitrates to high } \\
\text { crop yield, how runoff and water } \\
\text { pollution happens, and how } \\
\text { nitrates can affect people when } \\
\text { ingested. They can also provide } \\
\text { unbiased data and explain what } \\
\text { the data means. } \\
\text { Scientists could also help } \\
\text { develop technologies and } \\
\text { practices that could help prevent } \\
\text { fertilizer runoff and remove } \\
\text { nitrates from drinking water. }\end{array}$ \\
\hline
\end{tabular}

Table 7. Rubric and exemplars for the Affordances of Science and Non-Science Considerations dimension of SSR (Non-Science)

\begin{tabular}{|c|c|c|c|c|c|}
\hline & \multicolumn{5}{|c|}{ Levels } \\
\hline & 0 & 1 & 2 & 3 & 4 \\
\hline $\begin{array}{l}\text { Limitations of } \\
\text { Science }\end{array}$ & $\begin{array}{l}\text { Suggests that science would } \\
\text { not be helpful OR provides } \\
\text { an illogical response. }\end{array}$ & $\begin{array}{l}\text { Identifies one } \\
\text { way in which } \\
\text { non-science } \\
\text { considerations } \\
\text { would be } \\
\text { helpful for issue } \\
\text { resolution. }\end{array}$ & $\begin{array}{l}\text { Identifies one way in } \\
\text { which non-science } \\
\text { considerations would be } \\
\text { helpful and provides an } \\
\text { explanation or justification. }\end{array}$ & $\begin{array}{l}\text { Identifies two ways } \\
\text { in which non- } \\
\text { science } \\
\text { considerations } \\
\text { would be helpful } \\
\text { and provides an } \\
\text { explanation or } \\
\text { iustification for one. }\end{array}$ & $\begin{array}{l}\text { Identifies two ways in } \\
\text { which non-science } \\
\text { considerations would be } \\
\text { helpful and provides an } \\
\text { explanation or justification } \\
\text { for both. }\end{array}$ \\
\hline
\end{tabular}

Fixed choice

response:

The solution should

be determined by

\begin{tabular}{|c|c|c|c|c|c|}
\hline $\begin{array}{l}\text { science. } \\
\text { OR }\end{array}$ & Science & $\begin{array}{l}\text { Science and } \\
\text { other non- } \\
\text { science }\end{array}$ & $\begin{array}{l}\text { Science and other non- } \\
\text { science considerations }\end{array}$ & $\begin{array}{l}\text { Science and other } \\
\text { non-science } \\
\text { considerations }\end{array}$ & $\begin{array}{l}\text { Science and other non- } \\
\text { science considerations }\end{array}$ \\
\hline
\end{tabular}

science and other,

considerations non-science

Science and other non

non-science

considerations.

I am unsure what you mean by non-science. In my mind science is a pretty broad term. You need to be informed on the water chemistry (science) and the topography and runoff Exemplar Quote (science), the use of fertilize (ag science), implications affecting the city both financially and the health of its residents (science). It all, even the financial part, seems science related.
I think that having the The non-science most information would information that be better so that you can needs to be considered in order to determine a good solution include policies, socio-cultura and religious information. make a more informed decision. I think information about the economic impact of the options is important for al stakeholders. The cost of some sort of treatment and who is going to pay for these processes is important to find out.
Economics is a key ingredient that needs to be considered. If the cost is too high for one group to take on, the result would be economic downfall for them. Technology would be another thing to consider.
The financial cost to the solution should be considered. Perhaps it will just be too expensive for the farmers or the city to help pay for a solution. One must also consider any environmental factors that come into play. Perhaps part of a solution would be to clear a forest to make it available for crops--that might not be the best decision environmentally speaking.

\section{http://www.ejmste.com}

